\title{
A comprehensive approach to analyze discrepancies between land surface models and in-situ measurements: a case study over the US and Illinois with SECHIBA forced by NLDAS
}

\author{
M. Guimberteau ${ }^{1}$, A. Perrier ${ }^{2}$, K. Laval ${ }^{1}$, and J. Polcher ${ }^{1}$ \\ ${ }^{1}$ Laboratoire de Météorologie Dynamique (LMD), UMR8539 - CNRS, Vincent Cassé, Palaiseau, 05: Ile-de-France Ouest et \\ Nord, Paris, France \\ ${ }^{2}$ AgroParisTech, UFR Physique de l'Environnement, Paris, France \\ Correspondence to: M. Guimberteau (matthieu.guimberteau@upmc.fr)
}

Received: 2 March 2012 - Published in Hydrol. Earth Syst. Sci. Discuss.: 18 April 2012

Revised: 21 September 2012 - Accepted: 7 October 2012 - Published: 5 November 2012

\begin{abstract}
The purpose of this study is to test the ability of the Land Surface Model SECHIBA to simulate water budget and particularly soil moisture at two different scales: regional and local. The model is forced by NLDAS data set at 1/8th degree resolution over the 1997-1999 period. SECHIBA gives satisfying results in terms of evapotranspiration and runoff over the US compared with four other land surface models, all forced by NLDAS data set for a common time period. The simulated soil moisture is compared to in-situ data from the Global Soil Moisture Database across Illinois by computing a soil wetness index. A comprehensive approach is performed to test the ability of SECHIBA to simulate soil moisture with a gradual change of the vegetation parameters closely related to the experimental conditions. With default values of vegetation parameters, the model overestimates soil moisture, particularly during summer. Sensitivity tests of the model to the change of vegetation parameters show that the roots extraction parameter has the largest impact on soil moisture, other parameters such as LAI, height or soil resistance having a minor impact. Moreover, a new evapotranspiration computation including bare soil evaporation under vegetation has been introduced into the model. The results point out an improvement of the soil moisture simulation when this effect is taken into account. Finally, soil moisture sensitivity to precipitation variation is addressed and it is shown that soil moisture observations can be rather different, depending on the method of measuring field capacity. When the observed field capacity is deducted from the observed volumetric water profiles, simulated soil wetness index is closer to the observations.
\end{abstract}

\section{Introduction}

Land Surface Models (LSMs) are designed to simulate surface conditions with vegetation and soil parameters that are calibrated at global scale. However, many studies focus on regional scale for model validation or climate change impacts. It is therefore reasonable to ask if the LSMs parameters are able to represent surface conditions in agreement with local measurements. Thus, a comprehensive approach is performed in this study focused on water budget simulation at large scale over the US and particulary on soil moisture content at local scale over Illinois (Fig. 1). Soil moisture is a crucial component of the water cycle. It strongly influences the partition of surface fluxes between latent and sensible heat. It impacts on evapotranspiration (ET) and consequently on the turbulent fluxes into the boundary layer and also on surface runoff. In climate simulations using LSM coupled to Global Circulation Model (GCM), the capture of the variation of soil moisture state during the year is important in order to have realistic feedback between continental surface and atmosphere. Many works have focused on the sensitivity of LSMs fluxes to soil moisture (Dirmeyer et al., 2000). The aim of this article is to give an overview of the validity of three water cycle components simulated by the LSM SECHIBA (Schématisation des EChanges Hydriques à l'Interface Biosphère-Atmosphère, Ducoudré et al., 1993) at different spatial scales: ET, runoff and soil moisture. Over the US, the first two are compared with results of LSMs forced by the same North American Land Data Assimilation System (NLDAS, Cosgrove et al., 2003) forcing data set, at

Published by Copernicus Publications on behalf of the European Geosciences Union. 


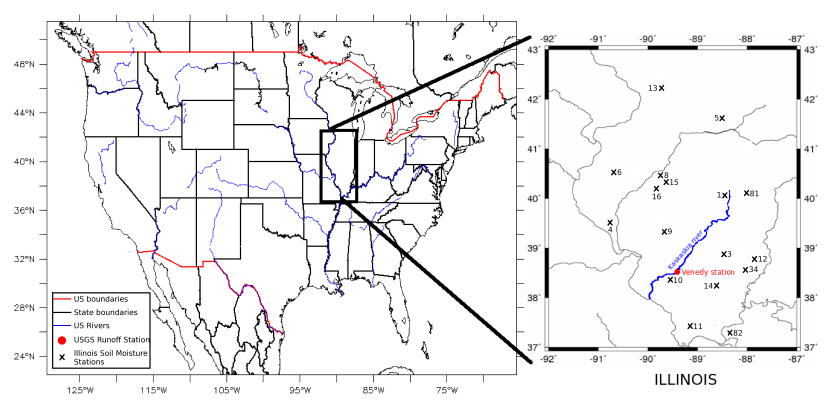

Fig. 1. Location of the Illinois state and the soil moisture stations. Kaskaskia river and Venedy station are also localized.

1/8th degree spatial resolution over the 1997-1999 period. Then, we focus over a smaller region of the US, the state of Illinois (Fig. 1), where in-situ soil moisture measurements have been performed and merged into a database by Robock et al. (2000). These observations are available for the studied time period (i.e. 1997-1999) and enable us to evaluate the SECHIBA results for simulated soil moisture. The ability of the LSM SECHIBA to simulate monthly variation in soil moisture is highlighted through a gradual and comprehensive adjustement of the vegetation parameters (LAI, root extraction, height). The impacts of the parameters modification on simulated soil moisture are studied. Then, the uncertainties of data set to assess the validity of the simulation are analysed. The role of precipitation rate during the studied period and the significance of defining field capacity are highlighted.

\section{Forcing data set and model}

\subsection{NLDAS forcing data set}

NLDAS forcing data set used to force the model covers all the United States and a part of Canada and Mexico. The hourly time resolution and the 1/8th degree latitudelongitude spatial resolution are quite high compared to the current forcing resolution for LSMs generally around 6 or $3 \mathrm{~h}$ and half degree, respectively. This high resolution is useful to investigate land surface processes at regional scales with better confidence and is therefore suitable for this study. NLDAS data set is a combination of Eta Data Assimilation System (EDAS) models outputs, observation-based precipitation and shortwave radiation data. Precipitation forcing was built with Stage II hourly Doppler Radar and River Forecast Center gauge data (Baldwin and Mitchell, 1997), Climate Prediction Center (CPC) daily gauge data (Higgins et al., 2000) and reprocessed daily gauge data. Observed shortwave values are derived from Geostationary Operational Environmental Satellite (GOES) radiation data processed at the University of Maryland and at the National Environmental Satellite data and Information Service (Pinker et al., 2003). The nine
Table 1. List of atmospheric forcing variables in NLDAS used for this study.

\begin{tabular}{|c|c|c|}
\hline Name & Description & Units \\
\hline$T_{\text {air }}$ & Two meters air temperature & $\mathrm{K}$ \\
\hline$Q_{\text {air }}$ & Two meters air specific humidity & $\mathrm{kg} \mathrm{kg}^{-1}$ \\
\hline Wind_N & Ten meters wind speed ( $u$ component) & $\mathrm{m} \mathrm{s}^{-1}$ \\
\hline Wind_E & Ten meters wind speed ( $v$ component) & $\mathrm{m} \mathrm{s}^{-1}$ \\
\hline$P_{\text {surf }}$ & Surface pressure & $\mathrm{Pa}$ \\
\hline $\mathrm{SW}_{\text {down }}$ & Surface downward short wave flux & $\mathrm{W} \mathrm{m}{ }^{-2}$ \\
\hline $\mathrm{LW}_{\text {down }}$ & Surface downward long wave flux & $\mathrm{W} \mathrm{m}^{-2}$ \\
\hline Rainf & Rainfall rate & $\mathrm{kg} \mathrm{m}^{-2} \mathrm{~s}^{-1}$ \\
\hline Snowf & Snowfall rate & $\mathrm{kg} \mathrm{m}^{-2} \mathrm{~s}^{-1}$ \\
\hline
\end{tabular}

primary forcing fields of the forcing used for this study are summed up in Table 1.

Precipitation is one of the most important forcing variables due to its strong impact on soil water budget and consequently on soil moisture content seasonality. NLDAS precipitation data come from a combination of model outputs and observations. Therefore, differences can be found with in-situ data results which can be important for regional scale simulations. In this study, NLDAS precipitation is compared with in-situ observations from 16 Illinois Climate Network (ICN) stations averaged over Illinois, during the time period 1997-1999. The mean annual value of NLDAS precipitation over the period $\left(2.73 \mathrm{~mm} \mathrm{~d}^{-1}\right)$ is $12 \%$ higher than observations $\left(2.44 \mathrm{~mm} \mathrm{~d}^{-1}\right)$. The highest overestimation occurs during spring and early summer (Fig. 2a). The overestimation is quasi-systematic during all three years (Fig. 2b). However, NLDAS precipitation variation is quite satisfying (linear correlation is about 0.97) where the wet summer in 1998 and the dry fall in 1999 are well captured.

\subsection{Model description}

SECHIBA is the hydrological module of the IPSL (Pierre Simon Laplace Institute) ORCHIDEE (ORganising Carbon and Hydrology In Dynamic EcosystEms) model and simulates the hydrological exchanges between soil, vegetation and atmosphere at a time-step of $\Delta t=30 \mathrm{~min}$.

\subsubsection{Vegetation and LAI}

In each grid-cell, up to twelve Plant Functional Types (PFTs) plus bare soil (see Table S1 for their prescribed default parameters) can be represented simultaneously. PFTs are prescribed by the $1 \mathrm{~km}$ global land cover map (International Geosphere Biosphere Programme (IGBP), Belward et al., 1999) reduced by a dominant-type method to $5 \mathrm{~km}$ spatial resolution with the Olson classification (Olson et al., 1983). Maximal fraction of vegetation $v\left(f_{v}^{\max }\right)$ is thus defined for each grid cell. It is modulated by the Leaf Area Index (LAI $v)$ growth, specific for each PFT represented in the model, giving the fraction of vegetation $f_{v}$ : 


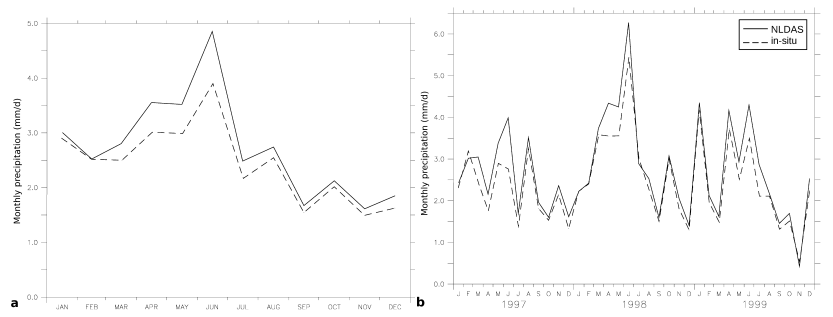

Fig. 2. Monthly mean (a) and monthly (b) precipitation $\left(\mathrm{mm} \mathrm{d}^{-1}\right)$ for NLDAS (black line) and in situ data (dashed line), for 19971999.

$f_{v}=f_{v}^{\max } \min \left(2 \mathrm{LAI}_{v}, 1\right)$.

The bare soil fraction $(v=1)$ increases linearly as much as the decrease of the other fractions of vegetation $(2 \leq v \leq 13)$ with a LAI lower than 0.5 :

$f_{1}=f_{1}^{\max }+\sum_{v=2}^{13}\left(f_{v}^{\max }-f_{v}\right)$

where $f_{1}^{\max }$ is the maximal fraction of bare soil.

The main method to simply simulate the LAI in the model is to prescribe it by a map (Belward et al., 1999) derived from Normalized Difference Vegetation Index (NDVI) observations. We choose to compute the LAI depending on the soil temperature variation at $50 \mathrm{~cm}$ depth $\left(T_{\text {soil }}\right.$ in $\left.\mathrm{K}\right)$ (Polcher, 1994), which has a smoothed seasonality during the year. This parameterization has been recently used in the model for a better LAI seasonality in numerical experiments of irrigation simulated by SECHIBA (Guimberteau, 2006, 2010). LAI growth is bounded by a minimal $\left(\mathrm{LAI}_{v}^{\mathrm{min}}\right)$ and a maximal value $\left(\mathrm{LAI}_{v}^{\max }\right)$ of LAI and depends on the soil temperature variation at $50 \mathrm{~cm}$ depth during the year, bounded by minimal $\left(T_{\text {soil }_{v}}^{\min }\right)$ and maximal values $\left(T_{\text {soil }}^{\max }\right)$ (both in $\mathrm{K}$ ) that can be different according to the PFT considered (Guimberteau, 2006, 2010).

$\mathrm{LAI}_{v}=\mathrm{LAI}_{v}^{\mathrm{min}}+f\left(T_{\text {soil }_{v}}\right)\left(\mathrm{LAI}_{v}^{\mathrm{max}}-\mathrm{LAI}_{v}^{\mathrm{min}}\right)$,

where $f\left(T_{\text {soil }_{v}}\right)$ (in $\mathrm{K}$ ) is the function of LAI growth for the PFT according to the soil temperature at $50 \mathrm{~cm}$ depth:

$f\left(T_{\text {soil }_{v}}\right)=\left[1-\left(\frac{T_{\text {soil }_{v}}^{\max }-T_{\text {soil }}}{T_{\text {soil }_{v}}^{\text {max }}-T_{\text {soil }_{v}}^{\text {min }}}\right)^{2}\right]$.

\subsubsection{Soil hydrology}

The parameterizations used in SECHIBA to represent hydrological processes are described in detail in Ducoudré et al. (1993) and D'Orgeval (2006). The two meters $\left(h_{\text {tot }}=2 \mathrm{~m}\right)$ soil column is often represented by two moisture layers

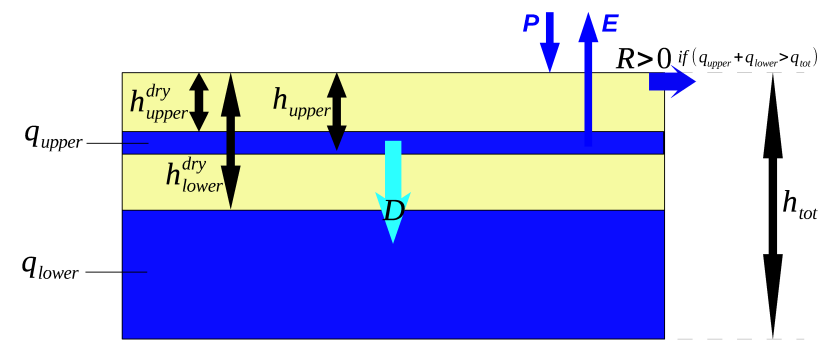

Fig. 3. Scheme of the soil hydrology in SECHIBA. $q_{\text {upper }}$ and $q_{\text {lower }}$ (both in $\mathrm{kg} \mathrm{m}^{-2}$ ) are the amount of water available for the plants contained in the upper and lower layers, respectively; $h$ dry and $h_{\text {lower }}^{\text {dry }}$ (both in $\mathrm{m}$ ), the depths of dry soil layers, over the superficial and the deep soil layer, respectively. $h_{\text {upper }}(\mathrm{m})$ is the height of the superficial layer, $R\left(\mathrm{~kg} \mathrm{~m}^{-2} \mathrm{~s}^{-1}\right)$ the runoff, $D\left(\mathrm{~kg} \mathrm{~m}^{-2} \mathrm{~s}^{-1}\right)$ the drainage between the two soil layers, $E\left(\mathrm{~kg} \mathrm{~m}^{-2} \mathrm{~s}^{-1}\right)$ the total evaporation and $P\left(\mathrm{~kg} \mathrm{~m}^{-2} \mathrm{~s}^{-1}\right)$ the precipitation.

(Fig. 3) depending on the soil column water balance according to ET and rainfall. The superficial layer is subjected to bare soil evaporation and root extraction, whereas the deep one is only related to deep root extraction according to their respective root density. The first layer has a resulting thickness generally smaller than the lowest one and its height ( $h_{\text {upper }}$ in $\mathrm{m}$ ) varies with the computed water extraction. The relative dryness of the layer is computed as the ratio between the actual soil water content in the layer and the maximum soil water content. The amount of water available for the plants in the upper layer $\left(q_{\text {upper }}\right.$ in $\left.\mathrm{kg} \mathrm{m}^{-2}\right)$ is directly controlled by the moisture convergence:

$\frac{\mathrm{d}}{\mathrm{d} t} q_{\text {upper }}=P-E-D$,

where $P=\operatorname{Rainf}+$ Snowf $\left(\mathrm{kg} \mathrm{m}^{-2} \mathrm{~s}^{-1}\right)$ is precipitation, $E$ $\left(\mathrm{kg} \mathrm{m}^{-2} \mathrm{~s}^{-1}\right)$ the total ET (i.e. the sum of water loss through bare soil evaporation, evaporation of water intercepted by the vegetation, transpiration of the cover and sublimation), and $D\left(\mathrm{~kg} \mathrm{~m}^{-2} \mathrm{~s}^{-1}\right)$ the drainage between the two soil layers (Ducharne et al., 1998; Dümenil and Todini, 1992; Rowntree and Lean, 1994). A schematic chart of the model used in this study can be found in Guimberteau et al. (2012) (Fig. 1).

The water budget is computed separately for each PFT tile within the mesh and then averaged over the grid cell. With this bucket model, we assume that runoff $\left(R\right.$ in $\left.\mathrm{kg} \mathrm{m}^{-2} \mathrm{~s}^{-1}\right)$ is produced only when the soil reaches field capacity (when $q_{\text {upper }}+q_{\text {lower }}>q_{\text {tot }}$ where $q_{\text {lower }}\left(\mathrm{kg} \mathrm{m}^{-2}\right)$ is the amount of water available for the plants in the lower layer and $q_{\mathrm{tot}}$ $\left(\mathrm{kg} \mathrm{m}^{-2}\right)$ the maximum amount of water that vegetation can draw from the soil). In the model, the total water excess (i.e. runoff) is prescribed as $95 \%$ in deep drainage $\left(\mathrm{kg} \mathrm{m}^{-2} \mathrm{~s}^{-1}\right)$ and $5 \%$ in surface runoff $\left(\mathrm{kg} \mathrm{m}^{-2} \mathrm{~s}^{-1}\right)$, which are only diagnosed.

The Soil Wetness Index (SWI) describes the soil moisture state and is useful to compare the different LSMs outputs 
(Dirmeyer et al., 2000) and also in-situ observations (Saleem and Salvucci, 2002). The SWI is used in our study to compare SECHIBA outputs and observations data. It gives a simple representation of the water stress for the vegetation and indicates the actual available soil water for plants at each time. SWI values range between 0 (wilting point) and 1 (field capacity):

$\mathrm{SWI}=\frac{W-W_{\text {wilt }}}{W_{\mathrm{fc}}-W_{\text {wilt }}}$,

where $W\left(\mathrm{~kg} \mathrm{~m}^{-2}\right)$ is the actual equivalent water depth stored in the soil, $W_{\text {wilt }}\left(\mathrm{kg} \mathrm{m}^{-2}\right)$ the equivalent water depth at the soil wilting point (determined by the soil and the vegetation properties) and $W_{\mathrm{fc}}\left(\mathrm{kg} \mathrm{m}^{-2}\right)$ the field capacity (based on soil texture alone), which represents the retained water in natural soil after gravitation action.

The simulated SWI (hereafter called "SWI $\mathrm{SECH}_{\text {") }}$ can be computed from the weighted average of the composite amount of water available for the plants into each PFT reservoir:

$\mathrm{SWI}_{\mathrm{SECH}}=\frac{q_{\text {upper }}+q_{\text {lower }}}{q_{\mathrm{tot}}}$,

where $q_{\text {tot }}$ is obtained by integrating the maximal soil water amount per unit of soil volume $\left(w_{\max }=150 \mathrm{~kg} \mathrm{~m}^{-3}\right)$ as

$q_{\mathrm{tot}}=h_{\mathrm{tot}} w_{\max }$.

\subsubsection{Evapotranspiration and root extraction}

\section{Evapotranspiration computation in the initial version of SECHIBA}

ET is a sum of four components: evaporation of water intercepted by the cover $\left(I_{v}\right.$ in $\left.\mathrm{kg} \mathrm{m}^{-2} \mathrm{~s}^{-1}\right)$, transpiration of vegetation $\left(T_{v}\right.$ in $\left.\mathrm{kg} \mathrm{m}^{-2} \mathrm{~s}^{-1}\right)$, bare soil evaporation $\left(E_{1}\right.$ in $\mathrm{kg} \mathrm{m}^{-2} \mathrm{~s}^{-1}$ ), and snow sublimation (not detailed here).

In the initial version of SECHIBA, the intercepted water is evaporated on the wet cover fraction ( $F_{\text {wet }}$, Eq. 9), which is the ratio between the amount of water (i.e. precipitation $P$ ) received by the leaf $\left(x_{v}=f_{v} P \Delta t, \mathrm{~kg} \mathrm{~m}^{-2}\right)$ and the maximal amount of intercepted water $\left(x_{v}^{\max }\right.$ in $\left.\mathrm{kg} \mathrm{m}^{-2}\right)$. The latter depends on the LAI and a coefficient $\alpha=0.1$ that converts LAI into size of interception loss reservoir (Eq. 10).

$\begin{aligned} F_{\text {wet }} & =\frac{x_{v}}{x_{v}^{\max }} \\ x_{v}^{\max } & =\alpha f_{v} \mathrm{LAI}_{v}\end{aligned}$

The evaporation of water intercepted by the cover $\left(I_{v}\right.$, Eq. 11) takes into account the structural (or architectural) resistance $\left(r_{\mathrm{s}_{v}}\right.$ in s m$\left.{ }^{-1}\right)$, and the aerodynamic resistance $\left(r_{\mathrm{a}}\right.$ in $\left.\mathrm{s} \mathrm{m}^{-1}\right)$.

$$
\begin{aligned}
I_{v} & =\min \left[X_{v}, f_{v} F_{\mathrm{wet}}\left(\frac{1}{1+\frac{r_{\mathrm{s} v}}{r_{\mathrm{a}}}}\right) E_{\mathrm{pot}}\right] \\
& =\min \left[X_{v}, I_{v}^{\max }\right],
\end{aligned}
$$

where $X_{v}=f_{v} P\left(\mathrm{~kg} \mathrm{~m}^{-2} \mathrm{~s}^{-1}\right)$ is the flux of water intercepted by the cover, $E_{\text {pot }}\left(\mathrm{kg} \mathrm{m}^{-2} \mathrm{~s}^{-1}\right)$ the potential evaporation (Budyko, 1956) and $I_{v}^{\max }\left(\mathrm{kg} \mathrm{m}^{-2} \mathrm{~s}^{-1}\right)$ the maximal evaporation of water intercepted by the cover.

On the dry fraction of the leaves $\left(F_{\mathrm{dry}}\right)$, transpiration $\left(T_{v}\right)$ is computed as a function of the canopy resistance (including both bulk stomatal and leaf aerodynamic resistances, $r_{\text {sto }_{v}}$ in $\mathrm{s} \mathrm{m}^{-1}$ ) and the root extraction potential $U_{\mathrm{s}_{v}}$ (De Rosnay and Polcher, 1998), which reproduces the ability of roots to extract water (detailed further down).

$$
\begin{aligned}
& F_{\mathrm{dry}}=1-\left(\frac{x_{v}}{x_{v}^{\max }}\right) \\
& T_{v}=f_{v} F_{\mathrm{dry}}\left(\frac{1}{1+\frac{r_{\mathrm{s}_{v}}+r_{\mathrm{stov}_{v}}}{r_{\mathrm{a}}}}\right) U_{\mathrm{s}_{v}} E_{\mathrm{pot}}
\end{aligned}
$$

Bare soil evaporation $\left(E_{1}\right)$ is computed through a resistance $\left(r_{1}\right.$ in $\left.\mathrm{s} \mathrm{m}^{-1}\right)$, proportional to the relative dryness of the upper soil layer $\left(h_{\text {upper }_{1}}^{\text {dry }}\right.$ in $\left.\mathrm{m}\right)$.

$$
\begin{aligned}
& E_{1}=f_{1}\left(\frac{1}{1+\frac{r_{1}}{r_{\mathrm{a}}}}\right) U_{\mathrm{s}_{1}} E_{\mathrm{pot}} \\
& r_{1}=h_{\mathrm{upper}_{1}}^{\text {dry }} r_{\mathrm{soil}},
\end{aligned}
$$

where $r_{\text {soil }}\left(\mathrm{s} \mathrm{m}^{-2}\right)$ is the resistance per dry soil meter. By default, it is set to $33000 \mathrm{~s} \mathrm{~m}^{-2}$, as introduced by Ducoudré et al. (1993).

\section{New evapotranspiration computation in SECHIBA}

According to Boone et al. (2004), ET simulated by SECHIBA is underestimated compared with other LSMs and especially the bare soil evaporation component. This weakness will be shown in the results of simulations SECH1 to SECH4 described in Sect. 5.2.1. Therefore, a new parameterization was implemented by D'Orgeval (2006) in the computation of water fluxes between soil, vegetation and atmosphere. This new parameterization will be tested in our study in simulations SECH5 and SECH6. The evaporation of the water intercepted by the cover is now computed over the total surface of the leaf. In a first approximation, each time the potential flux is not satisfied by intercepted water evaporation, the transpiration of the vegetation $\left(T_{v}^{\text {new }}\right.$, Eq. 16) takes over. It is constant as long as the sum of transpiration and intercepted water evaporation is lower than potential evaporation.

$T_{v}^{\text {new }}=\min \left[\left(I_{v}^{\max }-I_{v}\right), f_{v}\left(\frac{1}{1+\frac{r_{s_{v}}+r_{\text {sto }}}{r_{\mathrm{a}}}}\right) U_{\mathrm{s}_{v}} E_{\mathrm{pot}}\right]$

By this way, the sum of the evaporation of water intercepted by the leaves and the transpiration reaches the potential faster than in the previous parameterization. The total ET is consequently enhanced. 
Furthermore, the bare soil evaporation $\left(E_{1}^{\text {new }}\right.$, Eq. 19) is computed more realistically because a sub-fraction of bare soil uncovered by the vegetation $\left(f_{v}^{1}\right)$ is estimated by an extinction coefficient $(e=0.5)$, using an adapted Monsi and Saeki (1953) law:

$f_{v}^{1}=\exp \left(-e \mathrm{LAI}_{v}\right)$.

This sub-fraction will increase with the LAI decrease typically in fall and consequently enables bare soil evaporation under vegetation. A new bare soil fraction $\left(f_{1}^{\prime}\right)$ is defined in the model:

$f_{1}^{\prime}=\sum_{v=1}^{13} f_{v}^{1} f_{v}$

The bare soil evaporation is now computed over this new fraction:

$E_{1}^{\text {new }}=\min \left[f_{1}^{\prime}\left(\frac{1}{1+\frac{r_{1}}{r_{\mathrm{a}}}}\right) U_{\mathrm{s}_{1}} E_{\mathrm{pot}}, E_{\mathrm{pot}}-\sum_{v=2}^{13}\left(I_{v}+T_{v}^{\text {new }}\right)\right]$

\section{Root extraction}

Transpiration of the cover is governed by the ability of the roots to extract water from the soil (Desborough, 1997). This phenomenon is represented by the term $U_{\mathrm{s}_{v}}$ in ET equations (De Rosnay and Polcher, 1998). It decreases exponentially when dry soil depth increases in order to represent the potential of water extraction by the roots (Fig. 4). Its impact depends on the dry soil depth. Following rainfall events occurrence, the top soil layer might be saturated without any dry soil layer above. In this case, $h_{\text {upper }_{v}}^{\text {dry }}=0 \mathrm{~m}$ and $U_{\mathrm{s}_{v}}=1$. ET is consequently maximal (at the potential value weighted by a term of resistance) and the roots are more efficient in extracting water for transpiration. On the contrary, under dry conditions, the dry soil layer is formed and increases while $U_{\mathrm{S}_{v}}$ decreases exponentially approaching 0 . The model represents the difficulty for the roots to extract water all the more when their density is low. In order to simulate the different intensity to extract water according to the PFT, different values of the parameter $c_{v}$ (in $\mathrm{m}^{-1}$ ) have been attributed to each. Therefore, $U_{\mathrm{s}_{v}}$ is computed for each PFT and for each soil layer. Two cases can be distinguished:

1. if the superficial soil layer does not exist, there is only one root extraction potential (Eq. 20);

2. if the superficial soil layer is present, one root extraction potential is distinguished for each layer (Eqs. 20 and 21) and the maximum between both is selected (Eq. 22). The evaporation is thus favored by the upper part of the root system whose efficiency in contributing water to transpiration is higher than lower roots (De Rosnay and Polcher, 1998).

$U_{\mathrm{s}_{v}}^{\text {lower }}=\exp \left(-c_{v} h_{\text {tot }} \frac{h_{\text {lower }_{v}}^{\text {dry }}}{h_{\text {tot }}}\right)$

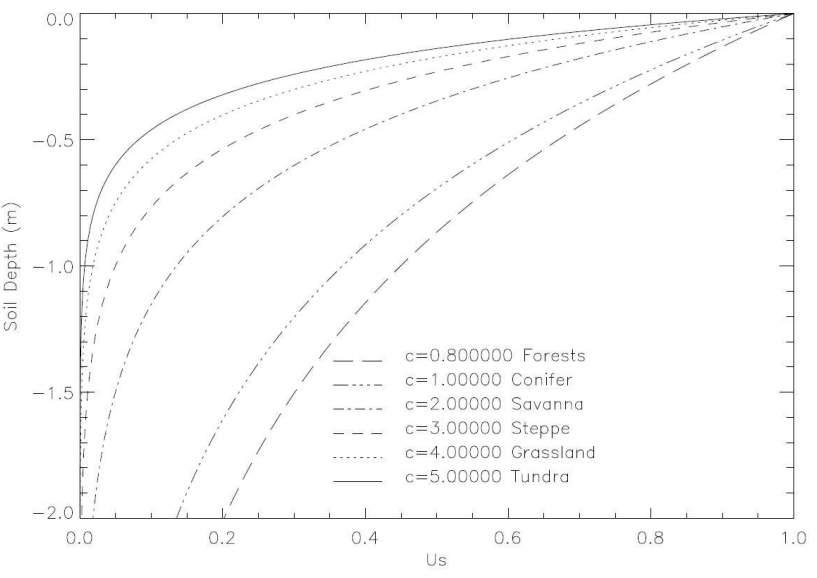

Fig. 4. Water uptake function, $U_{\mathrm{S}_{v}}$, for each canopy (De Rosnay and Polcher, 1998). The profiles depend on the dry soil depth and the value of the constant $c_{v}$.

$$
\begin{aligned}
& U_{\mathrm{s}_{v}}^{\text {upper }}=\exp \left(-c_{v} h_{\text {tot }} \frac{h_{\text {upper }_{v}}^{\text {dry }}}{h_{\text {upper }_{v}}}\right) \\
& U_{\mathrm{s}_{v}}=\max \left(U_{\mathrm{s}_{v}}^{\text {lower }}, U_{\mathrm{s}_{v}}^{\text {upper }}\right)
\end{aligned}
$$

\section{Experimental design}

The ability of the model SECHIBA to compute the water budget realistically at two different spatial scales is tested. At first, a simulation with SECHIBA is performed over the US (simulation SECH0, see Table 2) where mean annual ET (from initial computation in the model) and runoff results are compared with four LSMs (NOAH, National Centers for Environmental Prediction, Oregon State, University Air Force, Hydrology Lab, Betts et al., 1997; Chen et al., 1997; Ek et al., 2003; VIC, Variable Infiltration Capacity LSM, Liang et al., 1994; Wood et al., 1997; MOSAIC, Koster and Suarez, 1994, 1996; Koster et al., 2000; and SAC, Sacramento Soil Water Accounting Model, Burnash et al., 1973; Burnash, 1995) using the numerical experiments performed in Mitchell et al. (2004). The simulations by the five models including SECHIBA were performed for 1 October 1997 to 30 September 1999 with the same NLDAS forcing data set.

Then, the study is focused on the US state of Illinois where soil moisture content measurements were initiated by the Illinois Water Survey (Hollinger and Isard, 1994). Initially, the PFT distribution in SECHIBA is prescribed by the vegetation map. This distribution is compared with the vegetation cover on which the measurements were performed. Each measurement station is associated to the corresponding grid cell of the model, according to the coordinate of the station (see Table 3 and Fig. 1), as in Fig. 5. The vegetation cover of the 
Table 2. List of the simulations performed with their numerical settings over the US (simulation SECH0) and Illinois (simulations SECH1 to 6). Italic font indicates the altered value of a parameter compared to the previous parameterization. Columns 2 to 5 list the parameters specific to the PFT " $C_{3}$ crops" (simulation SECH1) gradually modified in grassland (simulation SECH3).

\begin{tabular}{lcccccccc}
\hline Simulations & $\begin{array}{c}T_{\text {soil }_{\mathrm{v}}}^{\min } ; T_{\text {soil }}^{\max } \\
\left({ }^{\circ} \mathrm{C}\right)\end{array}$ & LAI $_{\mathrm{v}}^{\min } ; \mathrm{LAI}_{\mathrm{v}}^{\max }$ & $\begin{array}{c}h \\
(\mathrm{~m})\end{array}$ & $\begin{array}{c}c_{\mathrm{V}} \\
\left(\mathrm{m}^{-1}\right)\end{array}$ & $\begin{array}{c}r_{\text {soil }} \\
\left(\mathrm{s} \mathrm{m}^{-2}\right)\end{array}$ & $\begin{array}{c}\text { Number of grid } \\
\text { cells for average }\end{array}$ & $\begin{array}{l}\text { Bare soil evaporation } \\
\text { under vegetation }\end{array}$ & $\begin{array}{l}\text { Precipitation } \\
\text { forcing }\end{array}$ \\
\hline SECH0 & $0 ; 20$ & $0 ; 2.0$ & 1.0 & 4.0 & 33000 & - & No & NLDAS \\
SECH1 & $0 ; 20$ & $0 ; 2.0$ & 1.0 & 4.0 & 33000 & 8 & No & NLDAS \\
SECH2 & $7 ; 15$ & $0 ; 3.5$ & 1.0 & 4.0 & 33000 & 8 & No & NLDAS \\
SECH3 & $7 ; 15$ & $0 ; 3.5$ & 1.0 & 1.0 & 33000 & 8 & No & NLDAS \\
- & $7 ; 15$ & $0 ; 3.5$ & 0.3 & 1.0 & 33000 & 8 & No & NLDAS \\
- & $7 ; 15$ & $0 ; 3.5$ & 0.3 & 1.0 & 330 & 8 & No & NLDAS \\
SECH4 & $7 ; 15$ & $0 ; 3.5$ & 0.3 & 1.0 & 330 & 17 & No & NLDAS \\
SECH5 & $7 ; 15$ & $0 ; 3.5$ & 0.3 & 1.0 & 330 & 17 & Yes & NLDAS \\
SECH6 & $7 ; 15$ & $0 ; 3.5$ & 0.3 & 1.0 & 330 & 17 & Yes & $I n$-situ \\
\hline
\end{tabular}

map differs from that on which the measurements were performed (i.e. grass cover). Figure 5a shows that few grid cells of the model are covered by grassland (grid cells containing stations 9,11 and 82) and less than $10 \%$ of their area is covered by this PFT. The prevailing type of vegetation over Illinois in the vegetation map is the PFT " $C_{3}$ crops" type. Eight grid cells containing stations are covered by the PFT " $C_{3}$ crops" at least by $90 \%$ (no. $1,5,6,8,9,13,15$ and 16) according to Fig. 5b. Consequently, a direct comparison cannot be established between results of integrated simulated soil moisture over the grid cell and the measurements until the proportion of one PFT is not above $90 \%$. So the first objective is to gradually replace " $C_{3}$ crops" PFT (that is prescribed in the model) into " $C_{3}$ grassland" PFT on these grid cells to ensure a good consistency between the LSM and the experimental ground conditions. This allows a better agreement with the local characteristics of the vegetation cover on which the measurements were performed, and an evaluation of the weight of each parameter that has been modified in the model, on simulated soil moisture.

For the control simulation over Illinois (SECH1, see Table 2), we undertake the study from the PFT distribution imposed by the vegetation map over the eight grid cells containing high proportion of " $C_{3}$ crops". First, gradual changes of crops parameters $\left(\mathrm{LAI}_{v}^{\max }, \mathrm{SECH} 2\right.$, see Table 2; root extraction parameter $c_{v}$ and crop height, $\mathrm{SECH} 3$, see Table 2) are performed. Then, we prescribed " $C_{3}$ grassland" PFT over all the grid cells (SECH4, see Table 2) and a test of the new ET computation (see Sect. 2.2.3) is performed (SECH5, see Table 2) to be closely related to the experimental conditions over a grass cover. At each step, the accuracy to simulate more realistically the SWI seasonal variation is highlighted when compared to the Illinois in-situ observations database (described in Sect. 4) over the 1997-1999 period. Secondly, soil moisture sensitivity to precipitation (SECH6, see Table 2) is studied. Moreover, we test a different evaluation of field capacity from measurements. Thirdly, simulated runoff
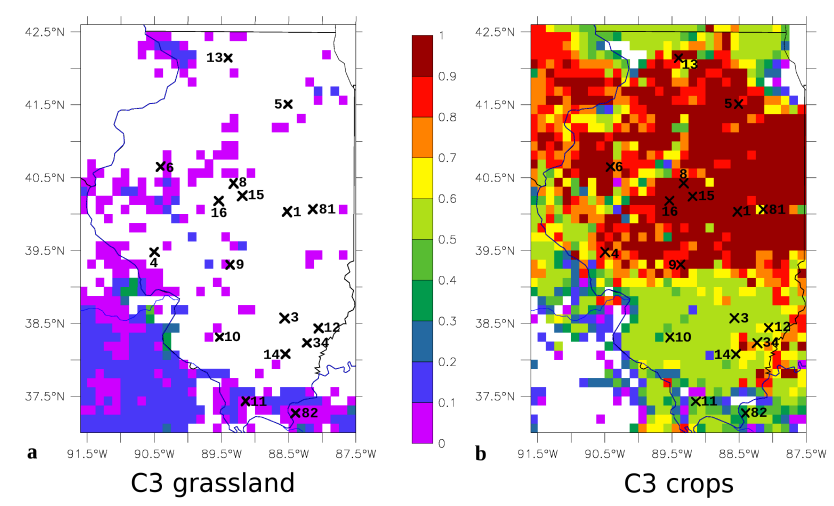

Fig. 5. Fraction of PFT (a) " $C_{3}$ grassland" and (b) " $C_{3}$ crops" covers on each grid cell across Illinois prescribed by the vegetation map in SECHIBA. The 17 soil moisture stations used for this study are indicated in the above figure (see Table 3 for their references).

is compared to observations over the Kaskaskia River basin in Illinois (see Fig. 1 for location).

For both US and Illinois simulations, a four-year spin-up has been performed over the same year 1997 to reach a state of equilibrium under the applied forcing.

\section{Soil moisture database}

Soil moisture data used in this study are part of the Global Soil Moisture Database (Robock et al., 2000), which gathered up to $30 \mathrm{yr}$ in-situ soil moisture recordings over more than 600 stations of many countries (such as Russia, China, Mongolia, India and US). The measurements in Illinois were performed with neutron probes, first at eight grass-covered sites in 1981 and then seven sites that were added in 1982 and two more in 1986. Finally, from 1992, nineteen ICN stations (see Table 3 ) collected data - especially soil moisture and precipitation. Soil moisture was continuously measured for 1981-2010 by 18 grass-covered stations and one station 
located on bare ground. They were taken within 11 soil layers to a depth of two meters: the first in the top $0.1 \mathrm{~m}$ of the profile, then every $0.2 \mathrm{~m}$ from a depth of $0.1 \mathrm{~m}$ through $1.9 \mathrm{~m}$, and the last in the layer between $1.9 \mathrm{~m}$ and $2.0 \mathrm{~m}$. Each site was visited twice each month: the week of the 15 th and the week of the last day of the month during March through September, and once each month during the last week of October through February (Hollinger and Isard, 1994). Except sand site at Topeka, silty loam (or silty clay loam for De Kalb and Champaign sites) is the predominant soil texture. In the 2-layer hydrology version of SECHIBA, soil texture is not taken into account so its impact on soil moisture content cannot be studied here.

\section{Results and discussion}

\subsection{Water balance simulated over the US}

Figure 6 shows the mean annual (based on October 1997September 1999 simulations described in Sect. 3) ET for the five LSMs (NOAH, VIC, MOSAIC, SAC and SECHIBA) over the US. The LSMs capture the spatial contrast between dry Western US where annual ET rate is generally less than $400 \mathrm{~mm} \mathrm{yr}^{-1}$, and humid Eastern US where annual ET rate is able to reach $800 \mathrm{~mm} \mathrm{yr}^{-1}$ and more. However, different patterns are simulated according to the models. The former are similar over the western region (except for California) between the models but differences in ET rates occur between VIC (Fig. 6b) and SAC (Fig. 6d) or MOSAIC (Fig. 6c) of about $100 \%$ over the Eastern US. SECHIBA (Fig. 6e) simulates an ET similar to NOAH (Fig. 6a), the values being often between $600 \mathrm{~mm} \mathrm{yr}^{-1}$ and $800 \mathrm{~mm} \mathrm{yr}^{-1}$ over the Eastern US for these two particular models. To establish the validity of the results, Mitchell et al. (2004) have used observed streamflow and annual discharges from 1145 basins and converted (using the basin area) to area-average mean annual runoff. They showed that mean annual runoff simulated by NOAH was in good agreement with runoff data over the southern and northern parts of Eastern US. Consequently, we conclude that ET rate simulated by NOAH is satisfactory, whereas VIC underestimates it (and overestimates runoff), and MOSAIC and SAC overestimate it. The fact that, over this region, ET rate distribution obtained with SECHIBA is similar to NOAH results is rather encouraging. Considering more precisely the Southeastern US region, we notice however that the ET rates simulated with SECHIBA are larger than with NOAH along the coast. This might be an improvement: actually, the study conducted by Mitchell et al. (2004) seems to show an annual runoff overestimation and consequently an ET rate underestimation. This difference is also found between NOAH and SECHIBA results over some parts of the Northeast US, although SECHIBA remains more similar to NOAH than to the three other models. Moreover, according to Mitchell et al. (2004), NOAH and VIC overestimate the runoff rate over
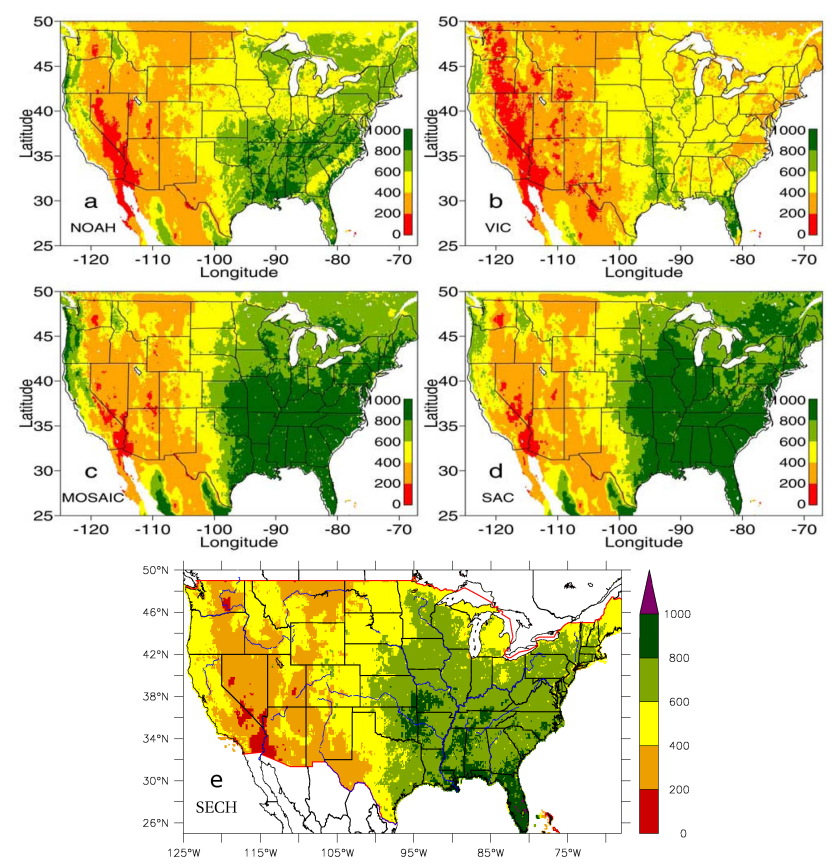

Fig. 6. Mean annual ET $\left(\mathrm{mm} \mathrm{yr}^{-1}\right)$ over the US, for the average period 1 October 1997-30 September 1999, from (a) NOAH, (b) VIC, (c) MOSAIC, (d) SAC and (e) SECHIBA. The first four maps were taken from Mitchell et al. (2004).

the state of Illinois (except for extreme northeast), the values being between 400 and $500 \mathrm{~mm} \mathrm{yr}^{-1}$, whereas MOSAIC and SAC underestimate the Illinois runoff (between 100 and $200 \mathrm{~mm} \mathrm{yr}^{-1}$ ). It is quite satisfying that SECHIBA gives an intermediate runoff of about $300-400 \mathrm{~mm} \mathrm{yr}^{-1}$ (not shown) compared to the other models. Orders of magnitude of ET and runoff simulated by SECHIBA seem to be satisfactory over the US and particularly in Illinois when compared to Mitchell et al. (2004). In the next section, in order to evaluate soil moisture, we focus our study on this state where many observations are available.

We note that after the completion of our study, a new comparison between observations and results from the same models were published (Xia et al., 2012b). These new simulations have been performed where the accuracy and consistency of the forcing data have been increased (NLDAS-2), the four LSMs code upgraded and the study time period extended to $30 \mathrm{yr}$ (1979-2008) (Xia et al., 2012a). Contrasting results are obtained between this last study (Xia et al., 2012b) compared to the previous ones (Mitchell et al., 2004). Xia et al. (2012b) found that NOAH model overestimates mean annual runoff (and thus underestimates mean annual ET), as SAC and VIC results are the closest to the observations. 
Table 3. List of measurements stations with their references (number, site code, coordinates and elevation). We do not take into account stations 2 and 17 for the present study.

\begin{tabular}{llcccc}
\hline Number & Name & Site code & Latitude $(\mathrm{N})$ & Longitude $(\mathrm{W})$ & Elevation $(\mathrm{m})$ \\
\hline 1 & Bondville & BVL & $40^{\circ} 03^{\prime}$ & $88^{\circ} 52^{\prime}$ & 213 \\
$2^{\mathrm{a}} / 82$ & Dixon Springs (bare /grass) & DXG & $37^{\circ} 27^{\prime}$ & $88^{\circ} 40^{\prime}$ & 165 \\
3 & Brownstown & BRW & $38^{\circ} 57^{\prime}$ & $88^{\circ} 57^{\prime}$ & 177 \\
4 & Perry & ORR & $39^{\circ} 48^{\prime}$ & $90^{\circ} 50^{\prime}$ & 206 \\
5 & De Kalb & DEK & $41^{\circ} 51^{\prime}$ & $88^{\circ} 51^{\prime}$ & 265 \\
6 & Monmouth & MON & $40^{\circ} 65^{\prime}$ & $90^{\circ} 41^{\prime}$ & 229 \\
8 & Peoria & ICC & $40^{\circ} 42^{\prime}$ & $89^{\circ} 32^{\prime}$ & 207 \\
9 & Springfield & LLC & $39^{\circ} 31^{\prime}$ & $89^{\circ} 37^{\prime}$ & 177 \\
10 & Belleville & FRM & $38^{\circ} 31^{\prime}$ & $89^{\circ} 53^{\prime}$ & 133 \\
11 & Carbondale & SIU & $37^{\circ} 43^{\prime}$ & $89^{\circ} 14^{\prime}$ & 137 \\
12 & Olney & OLN & $38^{\circ} 44^{\prime}$ & $88^{\circ} 06^{\prime}$ & 134 \\
13 & Freeport & FRE & $42^{\circ} 14^{\prime}$ & $89^{\circ} 40^{\prime}$ & 265 \\
14 & Ina & RND & $38^{\circ} 08^{\prime}$ & $88^{\circ} 55^{\prime}$ & 130 \\
15 & Stelle & STE & $40^{\circ} 25^{\prime}$ & $89^{\circ} 19^{\prime}$ & 207 \\
16 & Topeka & MTF & $40^{\circ} 18^{\prime}$ & $89^{\circ} 54^{\prime}$ & 152 \\
$17^{\mathrm{b}}$ & Oak Run & OAK & $40^{\circ} 58^{\prime}$ & $90^{\circ} 09^{\prime}$ & 265 \\
34 & Fairfield & FAI & $38^{\circ} 23^{\prime}$ & $88^{\circ} 23^{\prime}$ & 136 \\
81 & Champaign & CMI & $40^{\circ} 07^{\prime}$ & $88^{\circ} 14^{\prime}$ & 219 \\
\hline
\end{tabular}

${ }^{a}$ Measurements performed over bare soil for this station. ${ }^{b}$ Missing data for 1998 and 1999 for this station.

\subsection{Soil moisture simulated over Illinois}

\subsubsection{Progressive and comprehensive adjustements of vegetation parameters}

The SWI comparison between simulation and observations is first performed over the eight grid cells mentioned in Sect. 3 . Over Illinois, the mean SWI computed from observed soil moisture (hereafter called "SWIo") at 8 stations (Observations 8s) shows a pronounced seasonality during the year (Fig. 7a). It is maximal during winter and early spring, reaching 0.80 in March during the low ET period. The SWIo decreases during vegetation growth in spring to the middle of summer when climatic demand is maximal and thus water uptake by the vegetation significant. The SWIo remains low during fall with values around 0.40 . It shows a high variation during the three years, in averages, over Illinois where a dry event occurs during the fall 1999 and the SWIo value is less than 0.20 in November (Fig. 7b). This is due to the low precipitation occuring during this period over Illinois (less than $0.5 \mathrm{~mm} \mathrm{~d}^{-1}$ in November according to Fig. $2 b$ ).

SECHIBA does not reproduce the soil moisture seasonality when initial values of the vegetation parameters are used (SECH1 simulation, see Table 2). The soil is almost saturated throughout the year, even during summer months when only a $10 \%$ decrease is simulated (Fig. 7a). SECHIBA does not capture well the amplitude of soil moisture variations, with a variance $\left(3.77 \times 10^{-3}\right)$ largely underestimated compared to observations $\left(29.1 \times 10^{-3}\right)$. However, a seasonal variation is already noticed in agreement with observations (Fig. 7b).
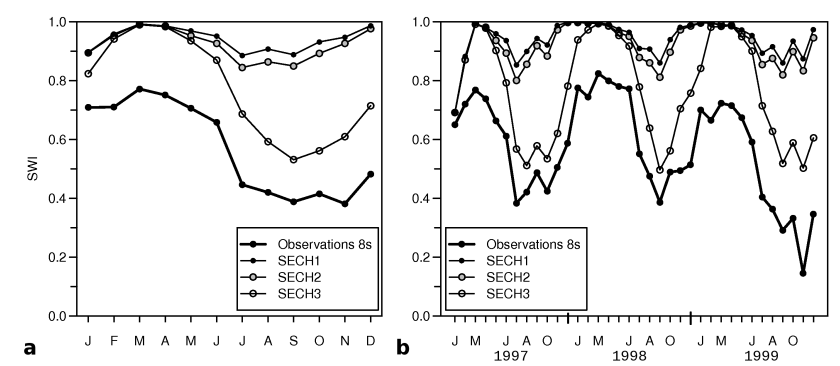

Fig. 7. Monthly mean SWI, averaged over the eight selected stations, from observations and simulations SECH1 to SECH3. (a) Averaged seasonal cycles and (b) time series over the period 19971999.

These remarks are confirmed over each of the eight grid cells (not shown).

Different hypotheses that could account for the global SWI overestimation by the model are successively highlighted and tested in this study. The vegetation parameters are gradually changed to be closer to the experimental conditions. First, the LAI parameterization is changed through two modifications (SECH2 simulation, see Table 2). The LAI maximum value initially equal to 2.0 increases to 3.5 , which corresponds to a very high maximal value of LAI for grassland (closer to the average value of 5.0 from Asner et al. (2003)'s LAI measurements synthesis). Specific values of soil temperature determining the LAI seasonality are now included as described in Sect. 2.2.1. We obtain a seasonal variation of LAI closer to a grass cover expected in such a temperate region like 


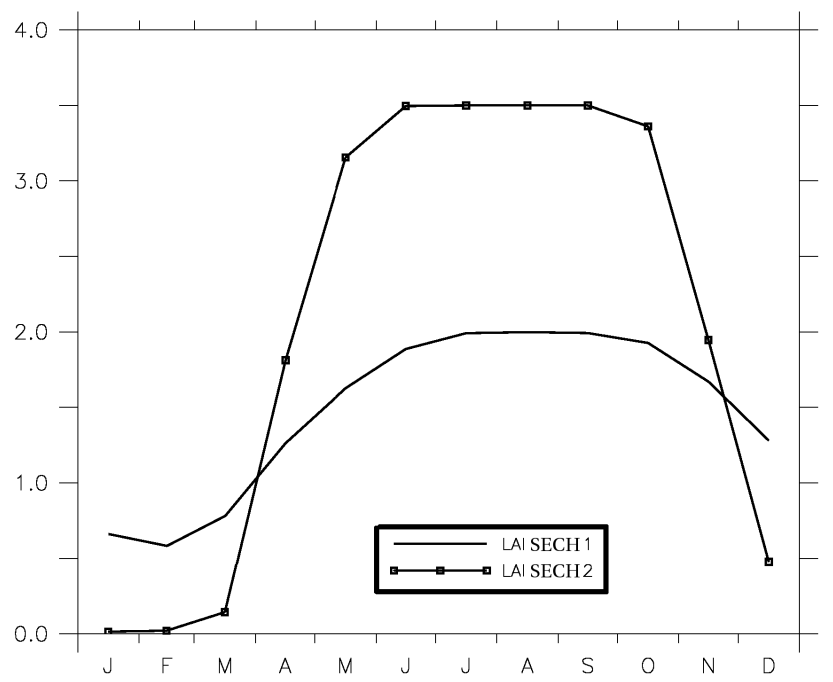

Fig. 8. 1997-1999 mean LAI seasonal cycle simulated from SECH1 and SECH2, averaged for the 8 validation grid cells (see Sect. 3 ).

Illinois: values are around zero during winter, whereas LAI increases rapidly during April to reach maximal values in summer and early fall (Fig. 8). The change of the minimum value of LAI had no significant impact on soil moisture (not shown). In fact, during winter, ET is limited by the amount of incident energy and the impact of the vegetation cover is negligible. The null value for the minimum LAI of grassland in SECHIBA is close to Asner et al. (2003)'s estimation equal to 0.3 . The effect of the LAI increase on soil moisture is not significant during winter (Fig. 7a) because the water uptake by the vegetation through transpiration is near zero and only bare soil evaporation is occurring in SECH2 simulation (see Fig. 9). A higher decrease in soil moisture content compared to simulation SECH1 is found during late spring (Fig. 7a) due to the enhanced transpiration of the cover, starting from the period of the vegetation growth (up to about $+0.3 \mathrm{~mm} \mathrm{~d}^{-1}$ in June for SECH2 compared to SECH1, not shown) converting more energy with a higher LAI. Moreover, plants intercept more precipitation (not shown). Thus, total ET increases even more during summer but $\mathrm{SWI}_{\mathrm{SECH}}$ remains overestimated compared to observations, with a mean relative error of variance greater than $80 \%$.

In order to improve the soil moisture seasonality and particularly its summer decrease, the ability of the roots to extract the water from the soil is enhanced. Therefore, the parameter $c_{v}=4.0 \mathrm{~m}^{-1}$ is put to $1.0(\mathrm{SECH} 3$ simulation, see Table 2). The roots density consequently increases, allowing a higher transpiration (up to $+1.5 \mathrm{~mm} \mathrm{~d}^{-1}$ in July compared to SECH2 according to Fig. 9). The significant effect of the roots on the transpiration corroborates the result of Feddes et al. (2001) who showed that transpiration is more responsive to the moisture content of a densely rooted soil layer. Moreover, De Rosnay and Polcher (1998) conclude

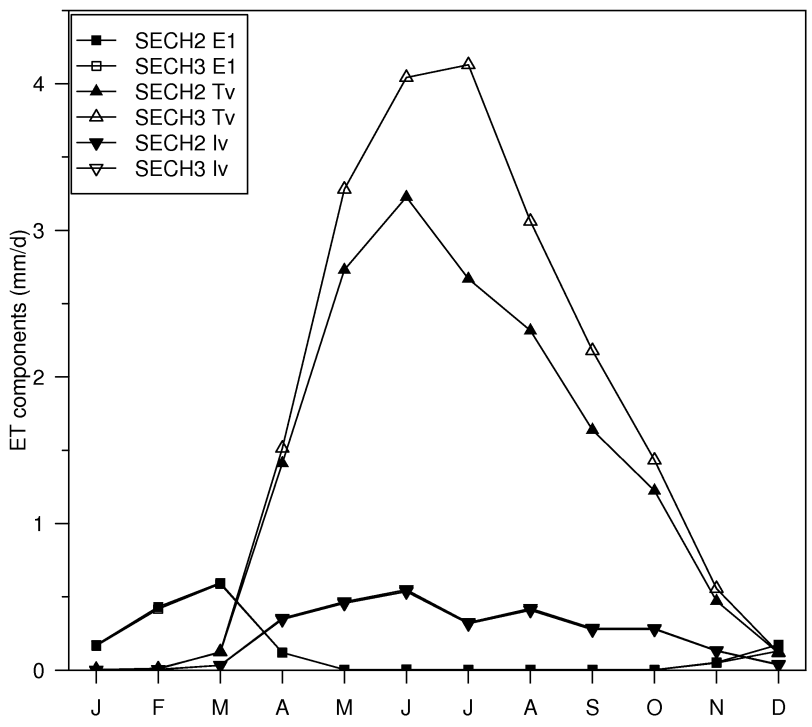

Fig. 9. Seasonal cycles of monthly mean ET components (sublimation not shown) $\left(\mathrm{mm} \mathrm{d}^{-1}\right)$ averaged over the eight validation grid cells, from SECH2 and SECH3, for the average period 1997-1999. ET components are $E_{1}$ (bare soil evaporation), $T_{v}$ (transpiration) and $I_{v}$ (evaporation of water intercepted by the cover).

that taking into account root profiles improves the representation of the seasonal cycle of transpiration. In our simulation, the roots have a strong impact on soil moisture content and improve the $\mathrm{SWI}_{\mathrm{SECH}}$ seasonal variation with a $7 \%$ mean relative error of variance. SWI $\mathrm{SECH}_{\mathrm{SE}}$ mainly decreases during the vegetation period in summer and fall (up to $37.5 \%$ in September compared to SECH2) (Fig. 7a). It is in better agreement with SWIo during fall for the years 1997 and 1998, whereas the high decrease observed in 1999 is not pronounced enough in SECH3 (Fig. 7b). Dry season results are different depending on the station. For example, at station 9, the pronounced $\mathrm{SWI}_{\mathrm{SECH}}$ decrease during fall with SECH3 simulation compared to SECH2 induces a better soil dryness capture during this season when compared to the SWIo (Fig. 10a). However, the simulated seasonality is poorly represented due to the soil moisture overestimation during spring in both simulations. At station 16, a lower $\mathrm{SWI}_{\mathrm{SECH}}$ decrease during spring induces a better seasonality, even a systematic overestimation throughout the year compared to the SWIo (Fig. 10b).

The vegetation height prescribed by default in the model is reduced from $1 \mathrm{~m}$ to $30 \mathrm{~cm}$, which is more realistic to represent a grass cover according to Allen et al. (1998) who gives a maximum height between 30 and $50 \mathrm{~cm}$. It has a little effect on soil moisture during fall (up to $6 \%$ of increase in October compared to SECH2, not shown) due to a slight ET decrease (not shown), the surface of exchanges of the plant with its atmosphere being reduced.

SECHIBA simulates a low bare soil evaporation (Fig. 9). The decrease in the bare soil evaporation resistance $\left(r_{\text {soil }}\right.$ is 

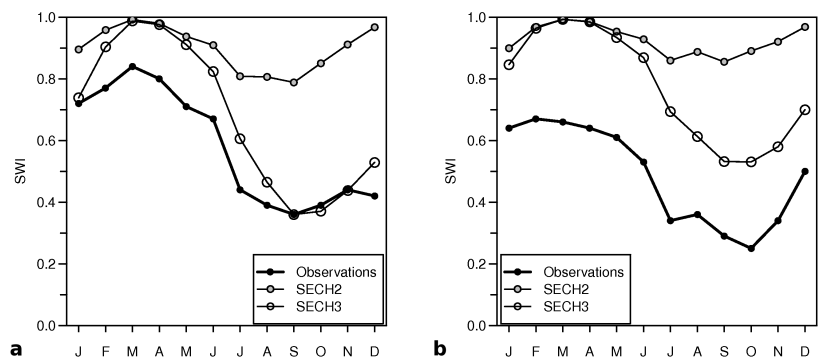

Fig. 10. Seasonal cycles of monthly mean SWI on (a) station 9 and (b) station 16, from observations and simulations SECH2 and SECH3 for the average period 1997-1999.
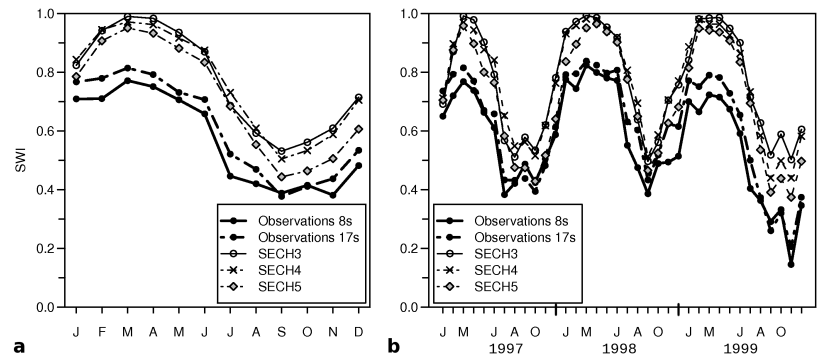

Fig. 11. Monthly mean SWI averaged over all the stations, from observations and SECH3 to SECH5. (a) Averaged seasonal cycles and (b) time series over the period 1997-1999.

divided per 100) has no significant impact on soil moisture (up to about $3 \%$ of decrease in March compared to SECH2, not shown). The results are quite similar over all the validation grid cells (not shown). This test shows that a value of $330 \mathrm{~s} \mathrm{~m}^{-1}$ for the resistance is already large enough to simulate the bare soil evaporation decrease when soil moisture is low.

In conclusion, a grass cover rather realistic is thus simulated with SECH3 where the maximum LAI is of 3.5 and the height of $30 \mathrm{~cm}$. The sensitivity tests highlight the major impact of the roots extraction on soil moisture content in our model. The value of $c_{v}=1.0 \mathrm{~m}^{-1}$ enables more water extraction from the first $50 \mathrm{~cm}$ of soil, and soil moisture shows a higher decrease during spring and summer in agreement with reality. The other parameters such as LAI and vegetation height or soil resistance have a minor impact.

Another comparison is carried out in which the sampling increases in order to improve the statistical study. A new simulation is performed (SECH4 simulation, see Table 2) where the vegetation parameterization in $\mathrm{SECH} 3$ is kept but the same PFT is setting everywhere on the grid cells of SECHIBA. This allows us to include the results from all the grid cells containing the stations. This simulation is relevant as far as there is no feedback from the surface to the atmosphere. Thus, the impacts of the vegetation around the studied grid cells can be left. When all the same vegetation type is set across the model grid, $\mathrm{SWI}_{\mathrm{SECH}}$ remains overestimated

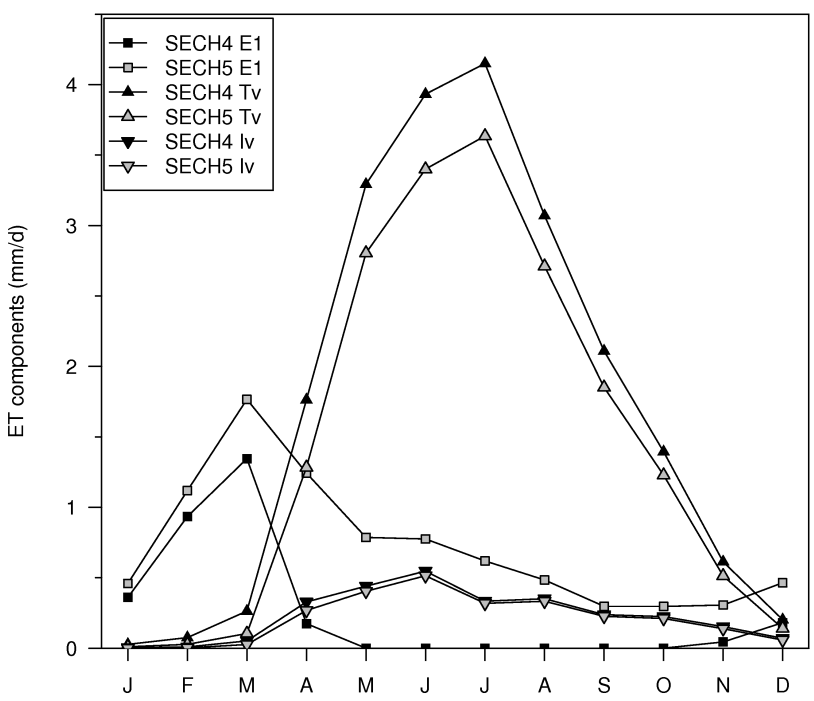

Fig. 12. Seasonal cycles of monthly mean ET components (sublimation not shown) $\left(\mathrm{mm} \mathrm{d}^{-1}\right)$ averaged over all the validation grid cells, from SECH4 and SECH5 for the average period 1997-1999. ET components are $E_{1}$ (bare soil evaporation), $T_{v}$ (transpiration) and $I_{v}$ (evaporation of water intercepted by the cover).
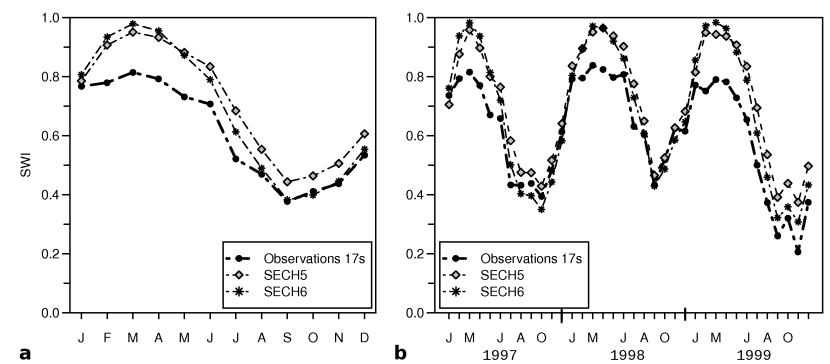

Fig. 13. Monthly mean SWI averaged over all the stations from observations, SECH5 and SECH6. (a) Averaged seasonal cycles and (b) time series over the period 1997-1999.

compared to the new average of observations (Observations $17 \mathrm{~s}$ ) according to Fig. 11a. However, the seasonal variation is slightly improved compared to SECH3 with a $3.1 \%$ mean relative error of variance. This improvement could account for the sampling increase improving the statistic for the simulation SECH4.

Simulated bare soil evaporation is low. Thus, a new ET computation which allows bare soil evaporation under the vegetation (see Sect. 2.2.3) is implemented in the model (simulation SECH5, see Table 2). In this simulation, the vegetation parameterization is the same as in SECH4. Bare soil evaporation is now simulated throughout the year with SECH5, even when vegetation is present during summer (Fig. 12). As long as the total available energy to evaporate does not change between the two simulations, the transpiration of the cover decreases (evaporation of water intercepted by the cover does not change significantly). The global ET 

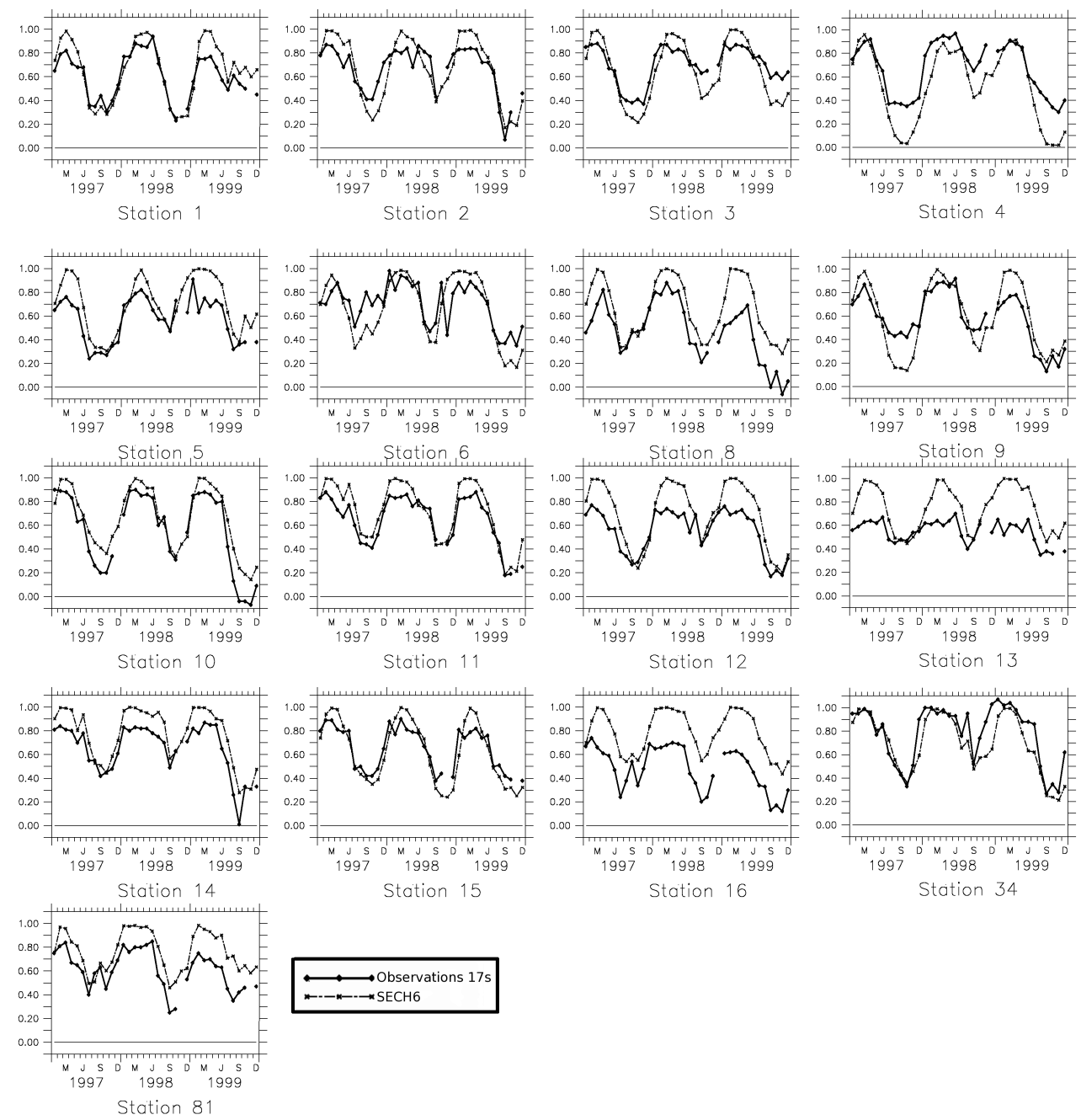

Fig. 14. Times series of monthly mean SWI for each studied stations, from observations and SECH6 for the period $1997-1999$.

increase $(+8.0 \%)$ improves the soil moisture seasonality in SECH5 compared to SECH4 (Fig. 11a). A soil moisture decrease occurs throughout the year and particularly during fall (up to $16 \%$ decrease in November). $\mathrm{SWI}_{\mathrm{SECH}}$ is mainly improved compared to measurements during the fall 1997 and 1998, whereas in fall 1999 it remains overestimated (Fig. 11b).

In conclusion, the adjustement of the potential of water extraction by the roots and the implementation of the new ET computation in the model are essential to simulate soil moisture in agreement with measurements on a more accurate scale.

\subsubsection{SWI variation according to precipitation data set}

The precipitation data set is crucial in soil moisture studies. As mentioned in Sect. 2.1, differences occur between NLDAS and in-situ observations. The NLDAS precipitation data is substituted by the in-situ precipitation for each station in the corresponding grid cell of the forcing grid. This allows an evaluation of soil moisture sensitivity to precipitation variation. The impact on soil moisture is then studied with simulation SECH6 (see Table 2), including vegetation parameterization and ET computation used in SECH5. Mean annual SWI simulated by SECHIBA forced by in-situ precipitation decreases compared to SECH5 (Fig. 13) where NLDAS precipitation is higher than in-situ measurements (see Sect. 2.1). This decrease occurs only during summer and fall, leading to a better agreement with the SWIo (Fig. 13a) and particularly for the year 1998 (Fig. 13b). The SWI SECH overestimation during the fall 1999 is greatly reduced when in-situ precipitation is used. It is closer to the measurements that pointed out more soil dryness than the two previous years during the same period (Fig. 13b). During winter and spring, SWI $\mathrm{SECH}_{\mathrm{S}}$ slightly increases compared to SECH5 and remains systematically overestimated compared to SWIo (Fig. 13a). This is also found in most of the stations (Fig. 14). 


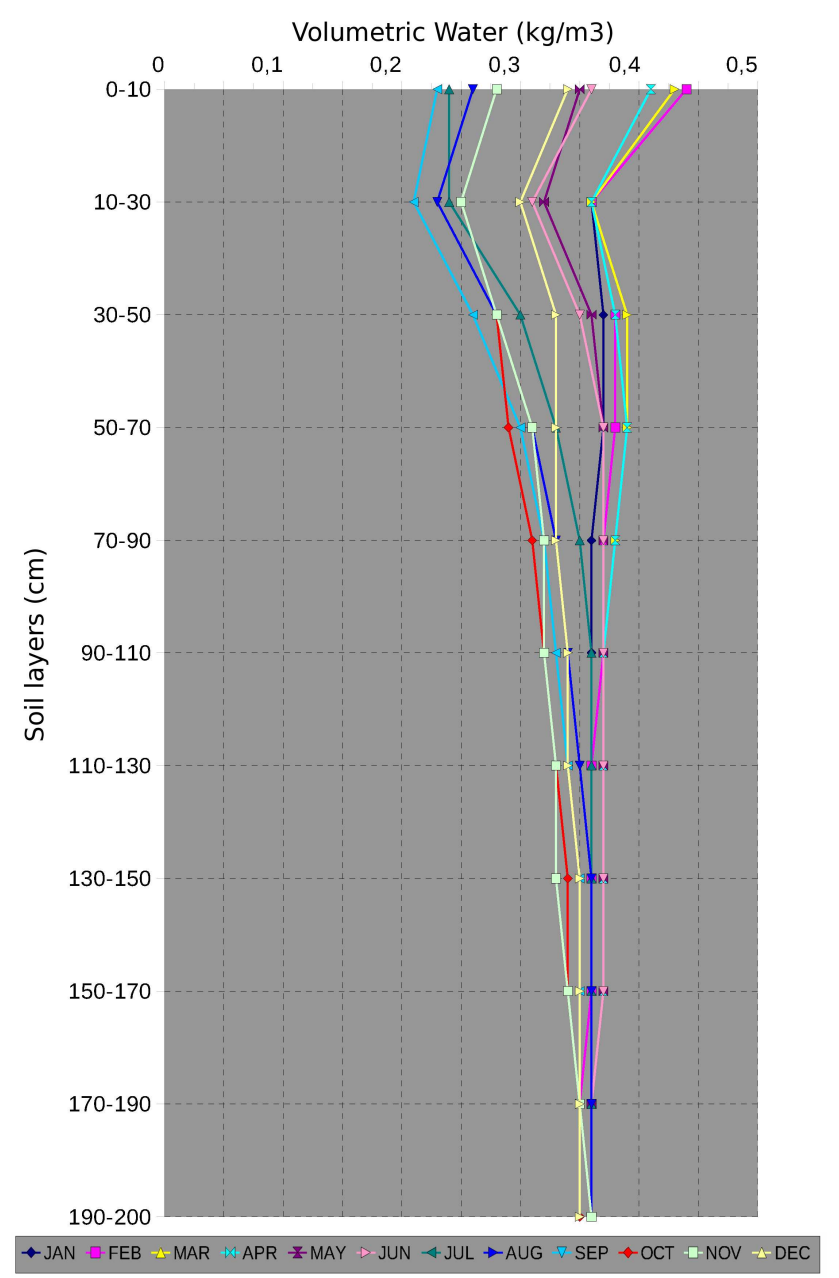

Fig. 15. Monthly mean volumetric water profiles averaged over all the stations for the period 1997-1999.

\subsubsection{A different method to get field capacity measured}

The estimation of field capacity measurement can be slightly different whether it is performed in laboratory or in-situ. Field capacity is usually measured in laboratory using "a pressure plate to apply a suction of $-1 / 3$ atmosphere to a saturated soil sample. When water is no longer leaving the soil sample, the soil moisture in the sample is determined gravimetrically and equated to field capacity." (Walker, 1989). Field method that consists in irrigating a test plot until the soil profile is saturated is particulary restrictive for this type of study. We suggest another method to measure the field capacity. It is considered as the maximal value of volumetric soil water content during the year. Thus, we plot the monthly observed volumetric water profiles in averages over the stations and the period (Fig. 15) to deduce the field capacity: the maximum volumetric water content during the year occurs in March on the $30-50 \mathrm{~cm}$ soil layer (we consider that the $0-10 \mathrm{~cm}$ layer is not representative of the field capacity at monthly time scale). This value

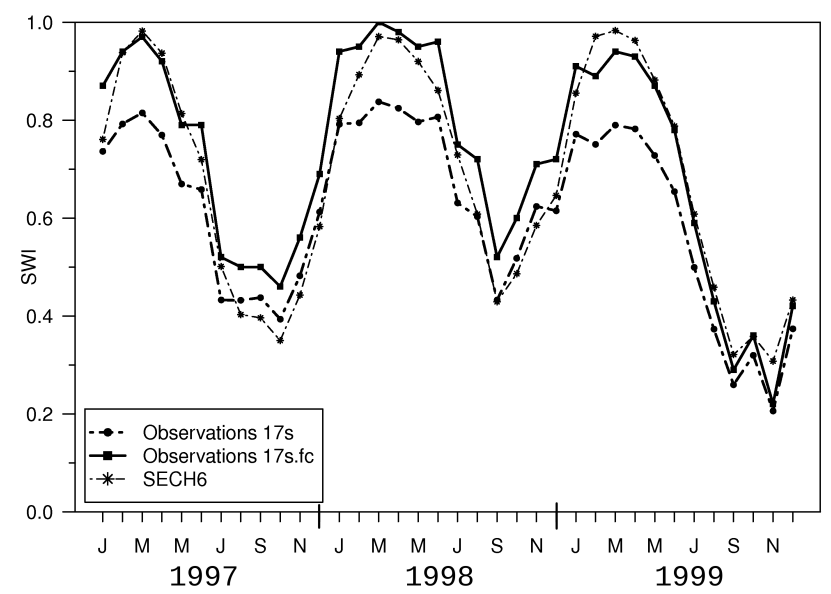

Fig. 16. Times series of monthly mean SWI averaged over all the stations, from observations, new profile of observations and SECH6 for the period 1997-1999.

deduced from the volumetric water profile $\left(0.39 \mathrm{~kg} \mathrm{~m}^{-3}\right)$ is lower than the measured field capacity $\left(0.41 \mathrm{~kg} \mathrm{~m}^{-3}\right)$. The SWIo is then recomputed with the new value of field capacity (corresponding to Observations 17s.fc in Fig. 16) and its seasonality is compared to $\mathrm{SWI}_{\mathrm{SECH}}$. The field capacity decrease in the re-computed SWIo leads to a SWIo increase particularly during winter and spring. SWI $_{\mathrm{SECH}}$ from SECH6 becomes consequently closer to the re-computed SWIo during the three years with a better similarity in seasonality amplitude (Fig. 16).

\subsubsection{Local-Global SWI analysis}

To summarize in detail our results with simulation SECH6, the amplitude and the phase of the SWI $\mathrm{SECH}_{\text {seasonality are }}$ represented for each station of Illinois (triangle) in the Taylor diagram (Taylor, 2001) (Fig. 17), which is frequently used in model evaluation studies. Overall, many stations show the SWI $_{\text {SECH }}$ in good agreement with the SWIo, including field capacity correction when SECHIBA is forced with in-situ precipitation and parameterized according to SECH6. Less than half of the stations present a relative error of SWISECH with observations around $10 \%$ and less. SECHIBA captures quite well the SWI seasonality phase over Illinois (more than $80 \%$ of stations shows a correlation greater than 0.85 ). The SWI amplitude, which is very different according to the station, is much harder to capture (about $50 \%$ of stations have a standard deviation of more or less 0.25 comparing to unit). SWI $_{\text {SECH }}$ seasonality at station 10 is the closest to the SWIo in terms of amplitude (ratio of standard deviation is close to 1), phase ( 0.98 of correlation) and magnitude $(17.5 \%$ of relative error). SWI at station 13 is the worst simulated because of its low observed amplitude, which SECHIBA cannot capture. 


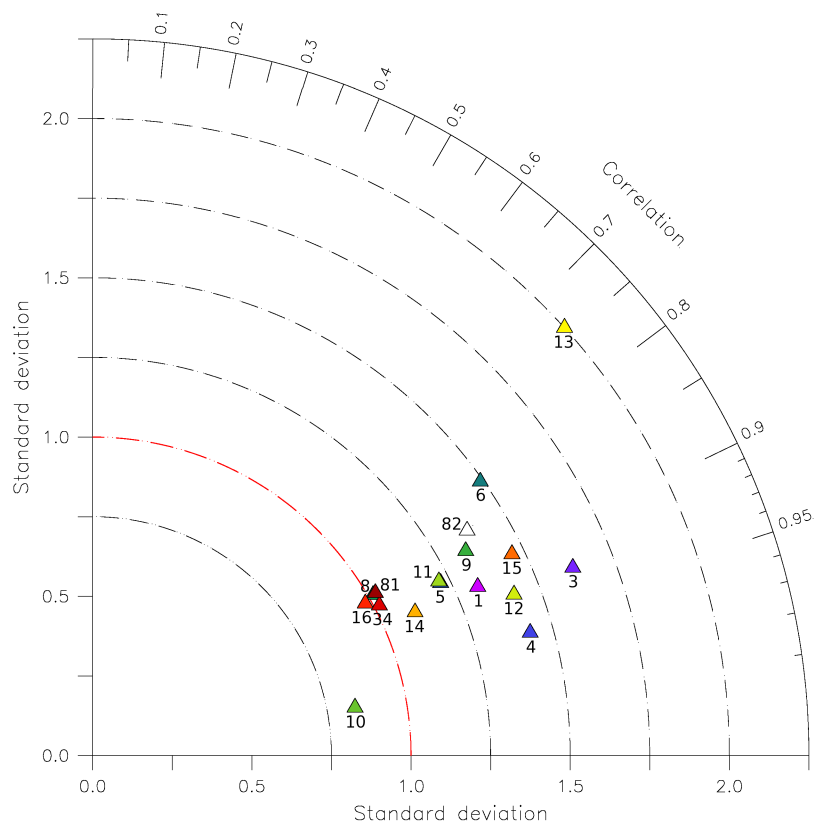

Fig. 17. Taylor diagram illustrating the statistics of $\mathrm{SWI}_{\mathrm{SECH}}$ from SECH6 from 1997 to 1999. Each station is represented by a colored triangle with its number. The Taylor diagram is a representation that provides the ratio of the simulated and the observed standard deviation as a radial distance from the origin and the correlation of $\mathrm{SWI}_{\mathrm{SECH}}$ with observations as the cosine of the azimuth angle in a polar plot. $R$ correlation coefficient is computed according to the following equation: $R=\frac{\frac{1}{N} \sum_{n=1}^{N}\left(\mathrm{SWI}_{n}^{\mathrm{SECH}}-\overline{\mathrm{SWI}^{\mathrm{SECH}}}\right)\left(\mathrm{SWI}_{n}^{\mathrm{OBS}}-\overline{\mathrm{SWI}^{\mathrm{OBS}}}\right)}{\sigma_{\mathrm{SWI}} \mathrm{SECH}_{\mathrm{SWI}} \sigma_{\mathrm{OBS}}}$, where $n$ is the month $(1<n<N=36)$, $\mathrm{SWI}^{\mathrm{SECH}}$ and $\mathrm{SWI}^{\mathrm{OBS}}$ are simulated and observed monthly mean SWI, respectively, and $\sigma_{\mathrm{SWI}} \mathrm{SECH}$ and $\sigma_{\mathrm{SWI}} \mathrm{OBS}$ are simulated and observed standard deviations, respectively. The mean SWIo averaged over all the stations is plotted at (1.0): no error in standard deviation and zero correlation error. The distance between the point (1.0) and the simulated result point is proportional to the root mean squared error. Good representation of the simulated amplitude compared to observations is represented by a triangle close to the dashed red line as radial distance. Good representation of the phase is materialized by a short distance between the triangle and the unit on the abscissa axis.

\subsection{Simulated runoff}

The resulting runoff simulated with SECH6 is compared with Kaskaskia streamflow data (divided by its corresponding basin surface) at Venedy station point $\left(38^{\circ} 27^{\prime} \mathrm{N} ; 89^{\circ} 37^{\prime} \mathrm{W}\right.$, Fig. 1), obtained from United States Geological Survey (USGS) for the period 1997-1999. This watershed is chosen because it integrates a large part of runoff over the southwest of Illinois. Simulated runoff is underestimated by $24 \%$. However, during the first half of the year, runoff is well simulated ( $2.5 \%$ mean relative error for the period January-May). SECHIBA succeeds in capturing the runoff peak observed in March (Fig. 18). During the rest of the year, the simulated

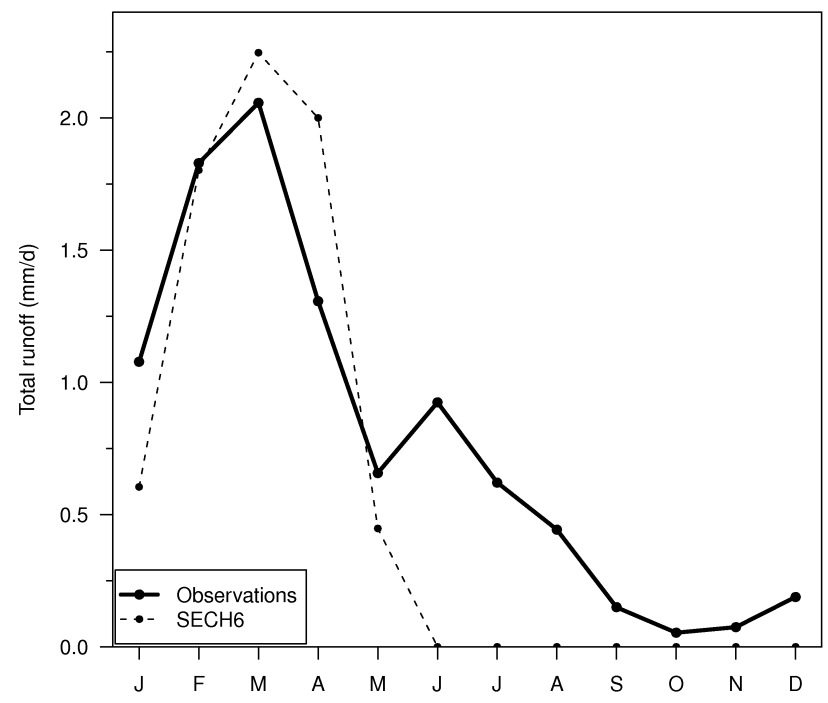

Fig. 18. Seasonal cycles of monthly mean runoff $\left(\mathrm{mm} \mathrm{d}^{-1}\right)$ on the grid cell corresponding to Venedy station coordinates, from observations and SECH6 for the average period 1997-1999.

runoff is null, leading to an underestimation in average over the year. This is partly due to the hydrological parameterization of the model, which cannot simulate runoff as far as soil moisture does not reach field capacity. In the model parameterization used for simulation SECH6, the improvement of root extraction potential generates a level of soil moisture content always far from the field capacity during summer and consequently exacerbates the limitation of the hydrological modelling to simulate runoff. Moreover, in the Illinois case, the top $2 \mathrm{~m}$ soil moisture variations can be constrained through reasonably unconfined aquifer modeling in terms of baseflow. For the top $1 \mathrm{~m}$ soil moisture, they are very sensitive to the LAI data, accurate modeling of shallow water table depths, and the parameterization of hydraulic conductivity (Yuan and Liang, 2011). The runoff underestimation by SECHIBA can be due to the complexity of the water exchange between the deep soil and the surface through the water table, which are included in the measurements data set but not represented in the model. The use of a multilayer approach to represent the vertical soil water diffusion and to parameterize hydraulic conductivity (De Rosnay, 1999; De Rosnay et al., 2002) should be more satisfactory to generate runoff and infiltration but it has not been tested in this study.

\section{Conclusions}

This paper investigated the ability of SECHIBA to compute the surface water balance at two different spatial scales. At large scale (over the US), ET and runoff results from SECHIBA, forced by NLDAS at 1/8th degree resolution, are in good agreement with NOAH, whose results are considered 
as the closest to observations. At local scale (over Illinois), soil moisture content simulated by SECHIBA forced by the same data set has been compared to observations from a global soil moisture database. When vegetation parameters are defined by experimental conditions, the model is able to capture rather well the soil moisture seasonal variation. The magnitude, amplitude and phase are well reproduced by the model over many stations. Uncertainties in climatic data, such as precipitation, that can induce a bias in the soil moisture simulations have been also pointed out. Further tests can be performed to assess the ability of SECHIBA to simulate soil moisture. A more challenging way could be to check if our model captures the top $1 \mathrm{~m}$ soil moisture variation. Over Illinois (1984-2008 period), Yuan and Liang (2011) showed that LSMs can reasonably capture the annual cycle and the inter-annual variability of the top $2 \mathrm{~m}$ soil moisture. However, they perform differently for the $1 \mathrm{~m}$ top soil, which is more responsive to many surface and subsurface hydrological processes. This requires a better knowledge of land surface parameters in LSMs such as root density and infiltration. Extensions of our study could be performed such as the use of the new hydrological module or the dynamical vegetation to improve soil moisture content simulation. Moreover, the study of the impact of soil texture on soil moisture content is a reliable perspective to extend this study. The improvement of spatial resolution is a big challenge for climate modelling and particularly for the LSMs which simulate land-use change. In this study, it is rather encouraging to obtain a realistic soil moisture seasonality at fine scale over Illinois with a global model such as SECHIBA that includes the simple hydrological module. Impact studies on water resources can be addressed with more confidence since soil moisture, which has a crucial impact on water cycle, is well represented. For example, Guimberteau et al. (2012) simulated with SECHIBA coupled with LMDZ (Laboratoire de Météorologie Dynamique Zoom, Hourdin et al., 2006) a significant summer precipitation decrease due to irrigation over the eastern part of the Mississippi River basin. Our comprehensive approach of gradual changes of the vegetation parameters over Illinois, which is part of this region, can lead to a better understanding of the processes between the irrigated vegetation cover and climate.

\section{Supplementary material related to this article is available online at: http://www.hydrol-earth-syst-sci.net/ 16/3973/2012/hess-16-3973-2012-supplement.pdf.}

Acknowledgements. We gratefully acknowledge Alan Robock for making available the soil moisture data bank of Illinois (Robock et al., 2000). We thank NLDAS team for making NLDAS forcing data set available. We also thank the two scientific software engineers Martial Mancip and Patrick Brockmann (both IPSL) for their help regarding NLDAS forcing building for SECHIBA and for the fusion of the observed precipitation in NLDAS fields, respectively. Simulations have been performed using computational facilities of the Institut du Développement et des Ressources en Informatique Scientifique (IDRIS, CNRS, France).

Edited by: B. Su

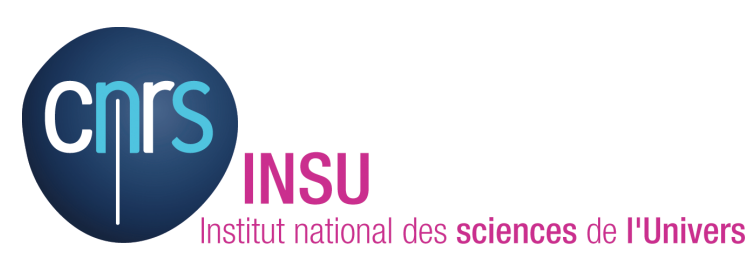

The publication of this article is financed by CNRS-INSU.

\section{References}

Allen, R. G., Pereira, L. S., Raes, D., and Smith, M.: Crop evapotranspiration-Guidelines for computing crop water requirements-FAO Irrigation and drainage paper 56, FAO Rome, 300, 6541, ISSN:0254-5284, 1998.

Asner, G. P., Scurlock, J. M. O., and Hicke, J. A.: Global synthesis of leaf area index observations: implications for ecological and remote sensing studies, Global Ecol. Biogeogr., 12, 191-205, doi:10.1046/j.1466-822X.2003.00026.x, 2003.

Baldwin, M. E. and Mitchell, K. E.: The NCEP hourly multisensor U.S. precipitation analysis for operations and GCIP research, Preprints, 13th Conference on Hydrology, Long Beach, CA, Am. Meteorol. Soc., 54-55, 1997.

Belward, A., Estes, J., and Kline, K.: The IGBP-DIS global 1-km land-cover data set DISCover: a project overview, Photogramm. Eng. Rem. S., 5, 1013-1020, 1999.

Betts, A., Chen, F., Mitchell, K., and Janjic, Z.: Assessment of the land surface and boundary layer models in two operational versions of the NCEP Eta model using FIFE data, Mon. Weather Rev., 125, 2896-2916, doi:10.1175/15200493(1997)125;2896:AOTLSA ¿2.0.CO;2, 1997.

Boone, A., Habets, F., Noilhan, J., Clark, D., Dirmeyer, P., Fox, S., Gusev, Y., Haddeland, I., Koster, R., Lohmann, D., Mahanama, S., Mitchell, K., Nasonova, O., Niu, G.-Y., Pitman, A., Polcher, J., Shmakin, A. B., Tanaka, K., van den Hurk, B., Vérant, S., Verseghy, D., Viterbo, P., and Yang, Z.-L.: The RhoneAggregation land surface scheme intercomparison project: an overview, J. Climate, 17, 187-208, 2004.

Budyko, M. I.: Heat Balance of the Earth Surface, Gidrometeoizdat, St. Petersburg, Russia, 255 pp., 1956 (in Russian).

Burnash, R. J. C.: The NWS river forecast system-catchment modeling, in Computer Models of Watershed Hydrology, edited by: Singh, V. P., 311-366, Water Resour. Publ., Littleton, Colo., 1995.

Burnash, R. J. C., Ferral R. L., and McGuire, R. A.: A generalized streamflow simulation system: Conceptual models for digital computer, technical report, Joint Fed. State River Forecast Cent., Sacramento, Calif., 1973.

Chen, T. H., Jankic, Z., and Mitchell, K.: Impact of atmospheric surface-layer parameterizations in the new land-surface scheme 
of the NCEP mesoscale Eta model, Bound.-Lay. Meteorol., 85, 391-421, doi:10.1023/A:1000531001463, 1997.

Cosgrove, B., Lohmann, D., Mitchell, K., Houser, P., Wood, E., Schaake, J., Robock, A., Marshall, C., Sheffield, J., Qingyuan, D., Lifeng, L., Higgins, R., Pinker, R., Tarpley, J., and Meng, J.: Real-time and retrospective forcing in the North American Land Data Assimilation System (NLDAS) project, J. Geophys. Res., 108, 8842, doi:10.1029/2002JD003118, 2003.

D’Orgeval, T.: Impact du changement climatique sur le cycle de l'eau en Afrique de l'Ouest: modélisation et incertitudes, $\mathrm{PhD}$ thesis, Université Paris VI, 2006.

De Rosnay, P.: Représentation de l'interaction sol-végétationatmosphère dans le modèle de circulation générale du Laboratoire de Météorologie Dynamique thesis, State Univ. Pierre et Marie Curie, Paris VI, 176 pp., 1999.

De Rosnay, P. and Polcher, J.: Modelling root water uptake in a complex land surface scheme coupled to a GCM, Hydrol. Earth Syst. Sci., 2, 239-255, doi:10.5194/hess-2-239-1998, 1998.

De Rosnay, P., Polcher, J., Bruen, M., and Laval, K.: Impact of a physically based soil water flow and soil-plant interaction representation for modeling large-scale land surface processes, J. Geophys. Res.-Atmos., 107, 4118, doi:10.1029/2001JD000634, 2002.

Desborough, C.: The impact of root weighting on the response of transpiration to moisture stress in land surface schemes, Mon. Weather Rev., 125, 1920-1930, 1997.

Dirmeyer, P., Zeng, F., Ducharne, A., Morrill, J., and Koster, R.: The sensitivity of surface fluxes to soil water content in three land surface schemes, J. Hydrometeorol., 1, 121-134, 2000.

Ducharne, A., Laval, K., and Polcher, J.: Sensitivity of the hydrological cycle to the parameterization of soil hydrology in a GCM, Clim. Dynam., 14, 307-327, 1998.

Ducoudré, N., Laval, K., and Perrier, A.: SECHIBA, a new set of parameterizations of the hydrologic exchanges at the land atmosphere interface within the LMD atmospheric global circulation model, J. Climate, 6, 248-273, 1993.

Dümenil, L., and Todini, E.: A rainfall-runoff scheme for use in the Hamburg climate model, In: J. O'Kane (ed.) Advances in theorical Hydrological Hydrology, A tribute to James Dooge, Vol. 1 of European Geophysical Society Series on Hydrological Sciences, Elsevier, 129-157, 1992.

Ek, M. B., Mitchell K. E., Lin, Y., Rodgers, E., Grunman, P., Koren, V., Gayno, G., and Tarpley, J. D.: Implementation of Noah land surface model advances in the National Centers for Environmental Prediction operational mesoscale Eta model, J. Geophys. Res., 108, 8851, doi:10.1029/2002JD003296, 2003.

Feddes, R., Hoff, H., Bruen, M., Dawson, T., De Rosnay, P., Dirmeyer, P., Jackson, R., Kabat, P., Kleidon, A., Lilly, A., and Pitman, A. J.: Modeling root water uptake in hydrological and climate models, B. Am. Meteorol. Soc., 82, 2797-2810, 2001.

Guimberteau, M.: Analyse et modifications proposées de la modélisation de l'irrigation dans un modèle de surface, Master's thesis, Université Paris VI and Laboratoire de Météorologie Dynamique Paris Jussieu, 2006.

Guimberteau, M.: Modélisation de l'hydrologie continentale et influences de l'irrigation sur le cycle de l'eau, PhD thesis, Université Paris VI and Laboratoire de Météorologie Dynamique Paris Jussieu, 2010.
Guimberteau, M., Laval, K., Perrier, A., and Polcher, J.: Global effect of irrigation and its impact on the onset of the Indian summer monsoon, Clim. Dynam., 39, 1329-1348, doi:10.1007/s00382011-1252-5, 2012.

Higgins, R., Shi, W., Yarosh, E., and Joyce, R.: Improved United States precipitation quality control system and analysis, NCEP/Climate Prediction Center Atlas, US Dept. of Commerce/Natl. Weather Serv. Natl. Oceanic and Atmos. Admin., Camp Springs, Md., 7, 40 pp., 2000.

Hollinger, S. and Isard, S.: A soil-moisture climatology of Illinois, J. Climate, 7, 822-833, 1994.

Hourdin, F., Musat, I., Bony, S., Braconnot, P., Codron, F., Dufresne, J.-L., Fairhead, L., Filiberti, M.-A., Friedlingstein, P., Grandpeix, J.-Y., Krinner, G., LeVan, P., Li, Z.-X., and Lott, F.: The LMDZ4 general circulation model: climate performance and sensitivity to parametrized physics with emphasis on tropical convection, Clim. Dynam., 27, 787-813, 2006.

Koster, R. and Suarez, M.: The components of the SVAT scheme and their effects on a GCM's hydrological cycle, Adv. Water Resour., 17, 61-78, doi:10.1016/0309-1708(94)90024-8, 1994.

Koster, R. and Suarez, M.: Energy and water balance calculations in the Mosaic LSM, NASA Tech. Memo., NASA TM-104606, Vol. 9, 60 pp., 1996.

Koster, R., Suarez, M., and Heiser, M. : Variance and predictability of precipitation at seasonal-to-interannual timescales, J. Hydrometeorol., 1, 26-46, doi:10.1175/15257541(2000)001;0026:VAPOPA $i 2.0 . C O ; 2,2000$.

Liang, X., Lettenmaier, D. P., Wood, E. F., and Burges, S. J.: A simple hydrologically based model of land surface water and energy fluxes for GCMs, J. Geophys. Res., 99, 14415-14428, doi:10.1029/94JD00483, 1994.

Mitchell, K., Lohmann, D., Houser, P., Wood, E., Schaake, J., Robock, A., Cosgrove, B., Sheffield, J., Duan, Q., Luo, L., Higgins, R., Pinker, R., Tarpley, J., Lettenmaier, D., Marshall, C., Entin, J., Pan, M., Shi, W., Koren, V., Meng, J., Ramsay, B., and Bailey, A.: The multi-institution North American Land Data Assimilation System (NLDAS): utilizing multiple GCIP products and partners in a continental distributed hydrological modeling system, J. Geophys. Res.-Atmos., 109, D07S90, doi:10.1029/2003JD003823, 2004.

Monsi, M. and Saeki, T.: Über den Lichtfaktor in den PflanzengePflanzengesellschaften und seine Bedeutung für die Stoffproduktion, Jpn. J. Bot., 14, 22-52, 1953.

Olson, J., Watts, J., and Allison, L.: Carbon in Live Vegetation of Major World Ecosystems (ORNL-5862), Environmental Sciences Division Publication, Oak Ridge National Lab., TN (USA), 1983.

Pinker, R., Tarpley, J., Laszlo, I., Mitchell, K., Houser, P., Wood, E., Schaake, J., Robock, A., Lohmann, D., Cosgrove, B., Sheffield, J., Duan, Q., Luo, L., and Higgins, R.: Surface radiation budgets in support of the GEWEX Continental-Scale International Project (GCIP) and the GEWEX Americas Prediction Project (GAPP), including the North American Land Data Assimilation System (NLDAS) Project, J. Geophys. Res.-Atmos., 108, 8844, doi:10.1029/2002JD003301, 2003.

Polcher, J.: Etude de la sensibilité du climat tropical à la déforestation, $\mathrm{PhD}$ thesis, Université Paris VI and Laboratoire de Météorologie Dynamique Paris Jussieu, 1994. 
Robock, A., Vinnikov, K., Srinivasan, G., Entin, J., Hollinger, S., Speranskaya, N., Liu, S., and Namkhai, A.: The global soil moisture data bank, B. Am. Meteorol. Soc., 81, 1281-1299, 2000.

Rowntree, P. R. and Lean, J.: Validation of hydrological schemes for climate models against catchment data, J. Hydrol., 155, 301323, 1994.

Saleem, J. and Salvucci, G.: Comparison of soil wetness indices for inducing functional similarity of hydrologic response across sites in Illinois, J. Hydrometeorol., 3, 80-91, 2002.

Taylor, K.: Summarizing multiple aspects of model performance in a single diagram, J. Geophys. Res.-Atmos., 106, 7183-7192, 2001.

Walker, W.: Guidelines for designing and evaluating surface irrigation systems, FAO, Rome, 1989.

Wood, E. F., Lettenmaier, D. P., Liang, X., Nijssen, B., and Wetzel, S. W.: Hydrological modeling of continentalscale basins, Annu. Rev. Earth Pl. Sc., 25, 279-300, doi:10.1146/annurev.earth.25.1.279, 1997.
Xia, Y., Mitchell, K., Ek, M., Sheffield, J., Cosgrove, B., Wood, E., Luo, L., Alonge, C., Wei, H., Meng, J., Livneh, B., Lettenmaier, D., Koren, V., Duan, Q., Mo, K., Fan, Y., and Mocko, D.: Continental-scale water and energy flux analysis and validation for the North American Land Data Assimilation System project phase 2 (NLDAS-2): 1. Intercomparison and application of model products, J. Geophys. Res., 117, D03109, doi:10.1029/2011JD016048, 2012a.

Xia, Y., Mitchell, K., Ek, M., Cosgrove, B., Sheffield, J., Luo, L., Alonge, C., Wei, H., Meng, J., Livneh, B., Duan, and Lohmann, D.: Continental-scale water and energy flux analysis and validation for North American Land Data Assimilation System project phase 2 (NLDAS-2): 2. Validation of model-simulated streamflow, J. Geophys. Res., 117, D03110, doi:10.1029/2011JD016051, 2012b.

Yuan, X. and Liang, X. Z.: Evaluation of a Conjunctive SurfaceSubsurface Process model (CSSP) over the contiguous US at regional-local scales, J. Hydrometeorol., 12, 579-599, 2011. 